\title{
Assessing the sustainability and equity of Alaska salmon fisheries through a well-being framework
}

\author{
$\underline{\text { Rachel Donkersloot }}^{1}, \underline{\text { Jessica C. Black }}^{2}$, Courtnev Carothers $^{2}$, Danielle Ringer $^{2}, \underline{\text { Wilson Justin }}^{3}$, Patricia M. Clav $^{4}, \underline{\text { Melissa R. Poe }}^{5}$, \\ Erika R. Gavenus ${ }^{6}$, William Voinot-Baron $^{7}$, Carrie Stevens ${ }^{2}$, Mike Williams $^{8}$, Julie Raymond-Yakoubian $^{9}$, Freddie Christiansen $^{10}$, \\ $\underline{\text { Sara Jo Breslow }}^{11}$, Stephen J. Langdon ${ }^{12}$, Jesse M. Coleman ${ }^{2}$ and S. Jeanette Clark ${ }^{13}$
}

\begin{abstract}
Salmon are intrinsic to health and well-being in Alaska, and sit at the center of myriad social, cultural, and spiritual practices, norms, and values. These practices and values are essential to living and being well in many communities in Alaska, but often remain invisible and unaccounted for in management contexts. This paper stems from the collective efforts of a cross-disciplinary, crosscultural project team brought together as part of the State of Alaska's Salmon and People (SASAP) knowledge synthesis project. In this paper, we assess the sustainability and equity of Alaska salmon systems through a well-being framework. Key objectives include (1) defining and conceptualizing well-being in the context of Alaska salmon systems; (2) developing and assessing well-being indicators for Alaska salmon systems; and (3) evaluating how well-being concepts are currently incorporated into Alaska salmon management and suggesting improvements. We draw on specific examples to evaluate the application of well-being indicators as a tool to more effectively measure and evaluate social considerations, and discuss how to better integrate well-being concepts into governance and management to improve data collection and decision making. As part of this effort, we discuss trends and inequities in Alaska fisheries and communities that impact well-being, and tensions between equality and equity in the context of Alaska salmon management.
\end{abstract}

Key Words: Alaska Native; equity; fishing communities; governance; indicators; salmon; well-being

\section{INTRODUCTION}

What are we conserving? The totality of our spiritual relations. Wilson Justin, Indigenous leader, Headwater People, State of Alaska's Salmon and People Working Group Meeting, 2018.

Salmon are intrinsic to health and well-being in Alaska (Boraas and Knott 2013, Langdon 2015, Raymond-Yakoubian 2019, Weiss $2020 a, b$; see also https://alaskasalmonandpeople.org). They sit at the center of myriad social, cultural, and spiritual practices, norms, and values that are essential to living and being well in many communities in Alaska; but these dimensions are often invisible and unaccounted for in management contexts (e.g., Taylor 2008, Donatuto et al. 2011, Hicks et al. 2016, Pascual et al. 2017, see also Raymond-Yakoubian et al. 2017, Raymond-Yakoubian and Daniel 2018). Human well-being has been widely promoted as an important dimension of sustainability (e.g., Millennium Ecosystem Assessment 2005, Stiglitz et al. 2009, 2018), and is increasingly gaining application in fisheries (e.g., Coulthard et al. 2011, Coulthard 2012, Breslow et al. 2016). At the same time, little progress has been made toward measuring the ways in which fisheries contribute to well-being beyond narrow economic indicators, e.g., ex-vessel values, fishery landings, employment, income (Sethi et al. 2014). Important dimensions of well-being, including intangible and subjective dimensions, remain understudied in science and policy realms yet are vital to cultural health, community sustainability, and successful management and policy solutions (see, for example, García-Quijano et al. 2015, Breslow et al. 2016). These dimensions include identity, social relationships, autonomy, generational connections to place and culture, and livelihood satisfaction, among others (Hicks et al. 2016, Pollnac et al. 2012, Pollnac and Poggie 2006).
Breslow et al. (2016) identify equity and justice as central to wellbeing. Equity is emerging as a focal area in the global fisheries literature as management systems produce outcomes, such as permit loss or lost/diminished access to traditional areas, disproportionately felt by Indigenous, rural, small-scale, and lowincome fishermen (FAO 2005, Pitcher and Power 2000, Carothers 2011, Pitcher et al. 2013, Black 2017, Song et al. 2018). Equity is a particularly salient topic in the context of Alaska salmon resource governance.

Equity is sometimes confused with equality (see Stiglitzet al. 2009, 2018 for broad discussion on equality and well-being). Although the terms are related, they are not synonymous. Equality refers to being equal; that is, the status, rights, opportunities, and so forth are the same for every person or group. Equity refers to fair or just; that is, the status, rights, opportunities, and so forth may depend on historic or current position, needs, and various other considerations that enable their enjoyment or access, and these may not be the same for every person or group. Since Alaska became a U.S. state in 1959, equality has been upheld as a legal and moral principle of the state's constitution. Equality guides natural resource management in Alaska that attempts to put every person on equal footing without regard to social and historical contexts, such as colonialism, social disruption, and resource dispossession, that have marginalized some people from access to resources and decision-making power. Harrison (2018:133) summarizes that "resource laws and regulations [in Alaska] must have ... a reasonable basis for distinctions they make among various users; they must put everyone on an equal footing within a group of users; and they may not prevent anyone from belonging to a particular user group."

${ }^{1}$ Coastal Cultures Research, ${ }^{2}$ University of Alaska Fairbanks, ${ }^{3}$ Mt. Sanford Tribal Consortium and Chistochina Enterprises, ${ }^{4}$ NOAA Fisheries, ${ }^{5}$ Washington Sea Grant, University of Washington, ${ }^{6}$ University of British Columbia, ${ }^{7}$ University of Wisconsin-Madison, ${ }^{8}$ Akiak Native Community and Kuskokwim River Inter-Tribal Fish Commission, ${ }^{9}$ Kawerak, Inc. ${ }^{10}$ Old Harbor Native Corporation, ${ }^{11}$ University of Washington, ${ }^{12}$ University of Alaska Anchorage, ${ }^{13}$ National Center for Ecological Analysis and Synthesis, University of California Santa Barbara 
The state constitution includes "equal access clauses" (Sections 3, 15 and 17 of Article 8) that guarantee that everyone be treated equally by management rules. This includes prohibiting the creation of special privileges or exclusive rights. Equality as applied to natural resource policy in Alaska ensures equal distribution or treatment, i.e., everyone is treated the same. Equity, on the other hand, acknowledges one's circumstance and relative position that influence the ability to benefit equally despite laws de jure. Furthermore, equity attends to outcomes and impacts that may be unequal as a result of circumstances and positions of power. In this paper, we pay special attention to equity (and inequity) as important for fostering (and eroding) well-being and sustaining Alaska salmon systems, and to tensions between equality and equity in this context that obfuscate clearer policies for social sustainability.

Salmon fisheries and communities in Alaska show increasing trends of inequities, a lack of fairness, in outcomes such as the erosion of rural and Alaska Native resource access, livelihoods, cultural practices, and self-determination. For thousands of years, salmon have been inherent to the existence and well-being of Alaska Native peoples. These salmon-human relationships continue today in language and knowledge, ceremonial life, political institutions, citizenship and social values, and worldviews (Simeone and Kari 2002, Fienup-Riordan and Moncrieff 2017, Stariwat 2016, Raymond-Yakoubian and Raymond-Yakoubian 2015), but have been reconfigured and in some cases displaced by colonizing and westernizing processes, practices, and knowledge and governance systems. ${ }^{[1]}$ Today these inequities are experienced across many dimensions, from the disproportionate impacts of climate change and differential access to resources and fishing opportunities (including the benefits that flow from fishing opportunities) to uneven capacity to participate in and influence management, data collection, and decision making (e.g., Krupa et al. 2019). Prominent examples include the dramatic loss of Alaska Native and rural local fishing rights as commercial permit holdings have shifted toward urban and out-of-state residents, and the loss of intergenerational access evident in the rising average age of commercial salmon fishermen in the state (see Fig. 1; Langdon 1980, Petterson 1983, Kamali 1984, Koslow 1986, Ringer et al. 2018). These trends are also evident in the loss and criminalization of traditional hunting and fishing livelihoods (Anderson 2016, 2018, Stariwat 2016, Black and Stevens 2019). ${ }^{[2]}$

Fig. 1. Net change in permit holdings by residency category, 1975-2016.

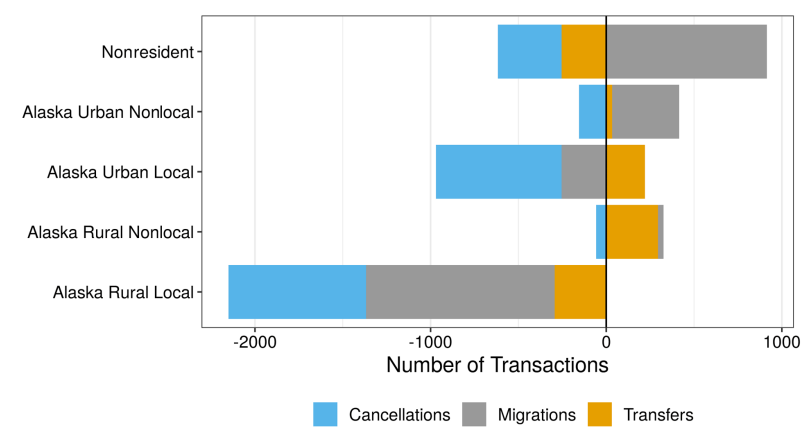

These kinds of inequities raise fundamental questions of social and community sustainability. Further, they highlight important directions to take in order to better integrate sociocultural information with biophysical aspects of salmon management in Alaska, and can help guide research priorities for management by identifying important missing indicators and data about social conditions for sustainable and equitable salmon management in Alaska. ${ }^{[3]}$

In this paper we assess the sustainability and equity of Alaska salmon systems through a well-being framework. Our key objectives include (1) defining and conceptualizing well-being in the context of Alaska salmon systems; (2) developing and assessing well-being indicators for Alaska salmon systems; and (3) evaluating how well-being concepts are currently incorporated into Alaska salmon management and suggesting improvements. This work is motivated not only by the need to better incorporate well-being concepts into salmon management and decision making in Alaska, but also the need to better account for how resource access contributes to well-being, and is influenced by diverse, complex, and oftentimes inequitable arrangements and opportunities that vary across communities and groups of people.

\section{METHODS}

To build a framework of well-being for Alaska salmon management, we convened a cross-disciplinary, cross-cultural project team brought together as part of the State of Alaska's Salmon and People (SASAP) knowledge synthesis project. We are a diverse working group of Indigenous and non-Indigenous scientists, practitioners, and knowledge bearers from across Alaska and the United States, with expertise representing a range of disciplines, organizations, and governmental bodies (for a complete list of project leads and workgroup members see: $\underline{\text { htps:// }}$ alaskasalmonandpeople.org/working-group/well-being-and-salmonsystems/). Working group members were selected for their geographic and disciplinary expertise, and background or leadership role in Alaska resource governance, community health and well-being, and Alaska Native livelihoods. In selecting team members, project leads attempted to balance academic and applied researchers and practitioners across generations, genders, and Alaska's many fishing regions. A specific contribution of our work is the prominence of Indigenous expertise and knowledge on our team. This expertise, frequently excluded from science and policy realms, guided our approach to well-being and foregrounded a fuller understanding of the impacts of western science and management systems in Alaska.

In 2017 and 2018, we convened two in-person, multiday working group meetings, one in Anchorage, Alaska and the other at the National Center for Ecological Analysis and Synthesis (NCEAS) in Santa Barbara, California. We also hosted multiple teleconferences. In our meetings, we explored several guiding questions, including the following: How do salmon-human connections contribute to various forms of well-being in Alaska? What dimensions of human well-being are currently understudied and/or overlooked in the context of Alaska salmon systems? How have human well-being concepts been incorporated into fishery management decision-making processes? What well-being measures can or should be applied to Alaska salmon resource governance? What information gaps currently exist? What can be done to enhance well-being in the context of Alaska salmon systems? 
We audio-recorded our meetings and transcribed all full-group dialogue. We inductively coded the transcriptions using Atlas.ti software. Coding and analysis was guided by grounded theory (Strauss and Corbin 1990), which is an iterative process whereby important topics emerge from the data during analysis (Bernard 2018). Coded text assisted with the identification of salient themes and potential well-being domains and dimensions. Our group also conducted an extensive literature review around core themes, including well-being in fishery systems, Indigenous well-being, well-being measurements and indicators, and resilience. This process aided in the development of a comprehensive list of wellbeing domains, and in identifying potential well-being indicators. We also reviewed multiple data sets provided by the Alaska Department of Fish and Game, Commercial Fisheries Entry Commission, U.S. Census Bureau, and others to assess potential indicators and data availability. All data sets are publicly available on the Knowledge Network for Biocomplexity web site at https:// knb.ecoinformatics.org/projects/SASAP/Data. As part of this work, we also ranked and evaluated several indicators. This is described in more detail in the section below on assessing wellbeing indicators.

Our in-person working group meetings were structured around the questions listed above and entailed full group discussion and several small group exercises. For example, as a first step in constructing a conceptual model for well-being in the context of Alaska salmon systems, group members free-listed all of the ways in which salmon contribute to well-being in Alaska. As another example, our full team reviewed, pile sorted, and ranked key wellbeing domains identified through an extensive literature review. We also identified and ranked more than 250 indicators according to specific criteria including conceptual validity, understandability, relevance, and measurability (see Breslow et al. 2016, 2017). Some methods, such as ranking exercises that directed someone to choose the most and least important ways that salmon contribute to well-being, were helpful in illuminating areas of consensus and divergent thinking among group members, but were viewed as inappropriate by some members.

\section{RESULTS}

How do you know that a system is healthy? That a community is well? That the individual has a strong spiritual soul, heart, mind and connection? You know by the way that they adopt the sharing component of community. Wilson Justin, Indigenous leader, Headwater People, Salmon and Society Workshop, Anchorage, Alaska, November 2016.

\section{Defining and conceptualizing well-being}

We define well-being as a way of being with others that arises when people and ecosystems are healthy, and when individuals, families, and communities equitably practice their chosen ways of life and enjoy a self-defined quality of life now and for future generations (see also McGregor 2008, Armitage et al. 2012, Breslow et al. 2016).

This definition captures not only economic or material well-being, but also important subjective elements of well-being such as how a person might perceive their own situation, e.g., happiness or job satisfaction, or "what an individual values doing and being" (Millennium Ecosystem Assessment 2005:V, see also Sen 1999,
Pollnac et al. 2012, García-Quijano et al. 2015). Moreover, our definition emphasizes equity and self-determination as fundamental to realizing well-being. In this definition, well-being includes human values and livelihood needs, and goes further to consider social relationships and future generations among the multiple dimensions of well-being (see, for example, Adelson 2000, White 2017).

Well-being as a practical concept can inform policy and decision making in important ways, but the concept also remains unwieldy and hamstrung by data availability and broad assumptions about people's needs, values, and perceived quality of life that may not fit specific local circumstances (Smith and Clay 2010, Breslow 2015, Hicks et al. 2016, see also Ragnarsdottir and ASAP Team 2014). The potential for misapplied measures is well documented among Indigenous communities, in particular, as they may not subscribe to taken-for-granted values prioritized in mainstream approaches to well-being (see, for example, Donatuto et al. 2011). This is evidenced in the above quote by Indigenous team member, Wilson Justin, who holds up sharing as a primary indicator of well-being.

Many Indigenous communities identify language and cultural continuity, autonomy, and traditional hunting and fishing livelihoods as essential to health and well-being (Young and Einarsson 2004, Poppel et al. 2007, Taylor 2008, Kovach 2010, García-Quijano et al. 2015, ICC Alaska 2015, Amberson et al. 2016, Braund 2017, von der Porten et al. 2019). These and other dimensions of well-being remain unaccounted for in dominant approaches to measuring quality of life, such as those that report on conventional, quantifiable standard of living metrics, e.g., household income, poverty and unemployment levels, education levels, and life expectancy (see Taylor 2008, Woodhead et al. 2018). Recognizing differences in how people define their own wellbeing, as well as differences in worldviews and values, is essential to developing sound well-being studies and metrics. As this example shows, it is the difference between measuring well-being by how much one has, i.e., an individual ownership model, versus how much one gives, i.e., a community sharing and relational model.

Our project team identified nine domains of well-being in the context of Alaska salmon systems (Fig. 2). The Social Well-Being Indicators in Marine Management (SWIMM) working group provided a basis for this conceptual work (note that three members of the SWIMM group are members of this project team; see also Hicks et al. 2016, Breslow et al. 2016, 2017). Breslow et al. $(2016,2017)$ developed a comprehensive framework for human well-being applicable to the entire U.S. West Coast. We honed this framework to better suit the context of Alaska salmon systems. Figure 2 features our well-being domains and their more specific dimensions of well-being (see Appendix 1 for complete list of well-being domains, dimensions, and definitions). For presentation, these domains and dimensions are organized as discrete categories, but many domains are interdependent and influence or overlap with others. For example, research has shown that social relationships are important to standards of living, and culture and identity can be central to health (see Morrow and Hensel 1992, Poppel et al. 2007, Wexler 2009).

Resource access is the prerequisite to being able to achieve one's well-being in the context of Alaska salmon systems. In our 
Fig. 2. State of Alaska's Salmon and People well-being domains and dimensions.

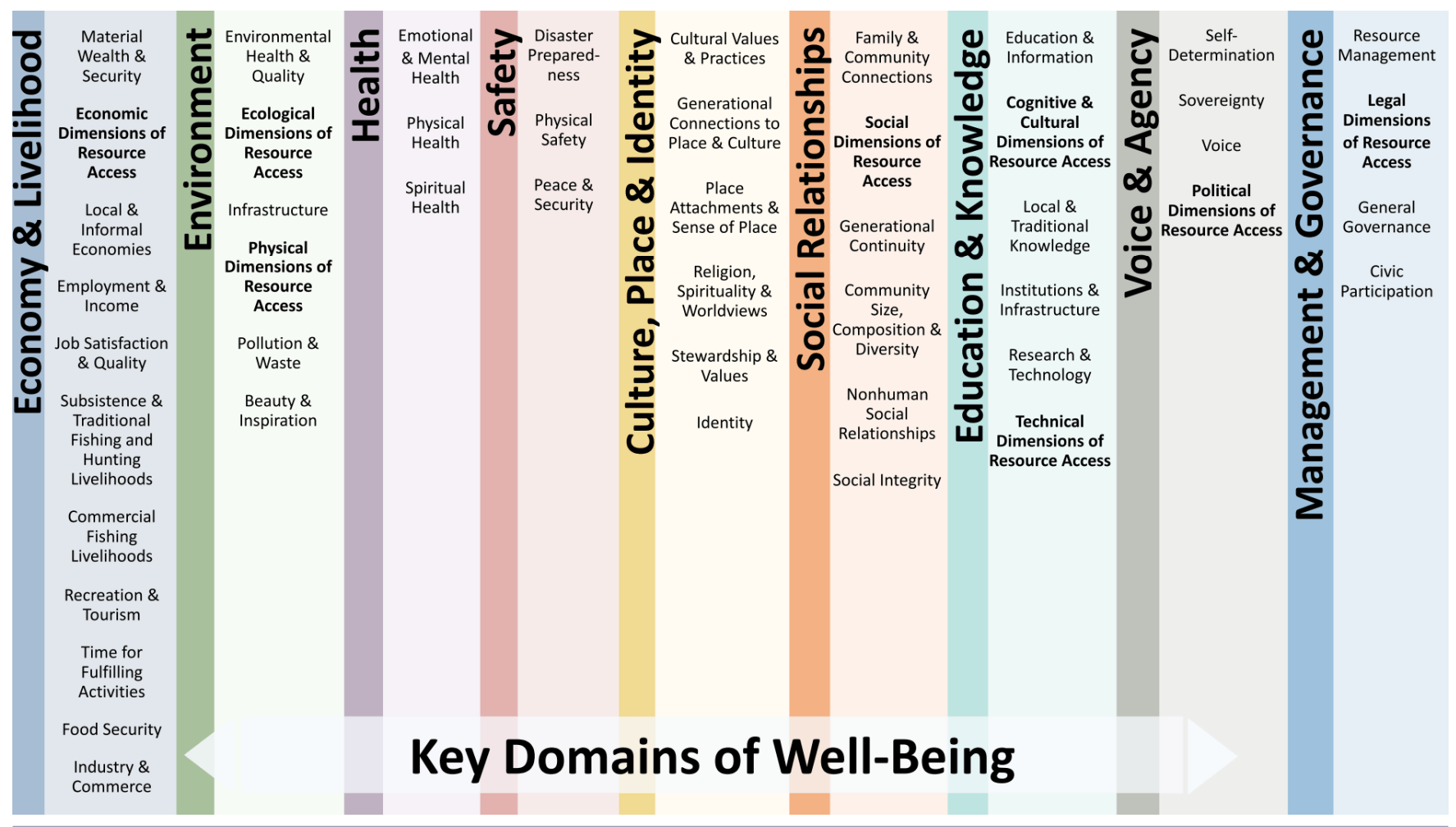

conceptual framework, resource access cuts across six of the nine well-being domains. Drawing again on the foundational work of Breslow et al. (2016, 2017), we identified economic, ecological, physical, social, legal, political, technical, cultural, and cognitive dimensions of resource access (see also Ribot and Peluso 2003). Our working group evaluated several community case studies to identify indicators that measure how dimensions of resource access contribute to well-being and can be enabled or constrained. Proposed indicators are discussed more fully below.

Developing and assessing well-being indicators for Alaska salmon systems

The use of indicators to assess well-being, while still modest, has gained considerable traction among maritime social scientists and fishery managers in the last 40 years (Smith and Clay 2010, Jepson and Colburn 2013, Clay et al. 2014, Colburn et al. 2016, Sterling et al. 2017). Much of this work has concentrated on the use of secondary data in the human dimensions of fisheries management and with that a bias toward easily quantifiable concepts (Jepson and Colburn 2013; for examples of recent work drawing on qualitative and primary data see Satterfield et al. 2013, Biedenweg 2014, Donatuto and Poe 2015, Poe et al. 2015, Leong et al. 2019).

Our team identified and ranked more than 250 objective, subjective, and relational indicators. Our review includes indicators operating across multiple scales including individual, household, community, fishery, and regional metrics. We ranked a broad range of indicators specific to Alaska salmon systems that can be used to measure well-being and signal changing trends, from "satisfaction with funding levels for salmon research and management" to "fishery participation costs" to "change in land ownership." For example, our working group discussed at length the relationship between land ownership, social values, and wellbeing, including how well-being can be threatened by land management decisions and the transfer of land ownership, such as with the sale of Native allotment lands, state land management and use decisions, and designations around the proposed development of Pebble Mine in the Bristol Bay region.

We considered resource access indicators in the context of multiple domains of well-being, such as financial circumstance, social networks, community infrastructure, health, political participation and representation, and environmental conditions. As one example, for rural fishing villages in the Kodiak Archipelago region, we identified "change in local permit holdings" and "percentage of local youth from fishing families who no longer fish" as indicators measuring the social dimensions of resource access. A recent survey of students in the rural Kodiak village of Ouzinkie shows that less than $25 \%$ of local youth have ever had any commercial fishing engagement, despite nearly all students having multigenerational family ties to fishing (Coleman et al. 2018). More broadly, these communities have suffered an $84 \%$ decline in the number of young salmon fishermen, i.e., permit holders under 40 years of age, compared to historic highs (Ringer et al. 2018). Another example of an access indicator measuring the economic dimensions of resource access might be "number or proportion of approved fishing loans by community." This indicator can help to show the flow of benefits from state loan programs, and how differential access to capital and lack of (or poor) credit disproportionately disadvantages rural and Alaska 
Table 1. Examples of sample well-being indicators identified by State of Alaska's Salmon and People working group.

\begin{tabular}{|c|c|c|c|}
\hline Domain & Dimension & Definition & Sample Indicator \\
\hline Economy and Livelihood & $\begin{array}{l}\text { Economic Dimension of Resource } \\
\text { Access }\end{array}$ & $\begin{array}{l}\text { Access to credit and capital needed } \\
\text { to invest in gear, permits, etc., } \\
\text { required for obtaining resource; } \\
\text { labor needed to harvest resource; } \\
\text { market value of resource and access } \\
\text { rights }\end{array}$ & $\begin{array}{l}\text { Value of fishery access rights } \\
\text { compared to median household } \\
\text { income }\end{array}$ \\
\hline Social Relationships & $\begin{array}{l}\text { Social Dimensions of Resource } \\
\text { Access }\end{array}$ & $\begin{array}{l}\text { Social context, identity, and } \\
\text { networks of the resource user that } \\
\text { enable, confer, or deny rights of } \\
\text { access, e.g., ethnicity, kinship, group } \\
\text { membership }\end{array}$ & $\begin{array}{l}\% \text { of residents with historical ties to } \\
\text { fishery that no longer fish }\end{array}$ \\
\hline Management and Governance & Resource Management & $\begin{array}{l}\text { Governmental management of } \\
\text { natural resources, including } \\
\text { governing institutions, self- } \\
\text { governance, and tribal or local } \\
\text { sovereignty; perceptions and } \\
\text { effectiveness of management; } \\
\text { capacity for achieving management } \\
\text { objectives }\end{array}$ & $\begin{array}{l}\text { Diversity of salmon users included } \\
\text { in management }\end{array}$ \\
\hline
\end{tabular}

Native fishermen wanting to enter into commercial fisheries (see Apgar-Kurtz 2015, Ruby and Heyano 2016, Cullenberg et al. 2017). Additional examples of indicators created and ranked by our project team (within established domains) are listed in Table 1 .

Our working group also ranked indicators that were adopted or adapted from existing projects with similar objectives (see Poppel et al. 2007, Breslow et al. 2016, 2017, Biedenweg 2014, Braund 2017). We assigned each indicator to a specific well-being domain and dimension. Examples include the following:

- $\%$ of local residents who are satisfied with their access to public shorelines or fish sites, e.g., fish wheels, setnet sites (environment/infrastructure)

- $\%$ of residents who have thought about moving away from the community in the past five years (social relationships/ community size, composition, and diversity)

- $\%$ of residents able to participate in salmon-related cultural activities or traditions that are important to family or community, and ease or difficulty of maintaining these (culture, place, and identity/cultural values and practices)

- $\%$ of residents who express high life satisfaction or happiness and $\%$ who describe living in the region as a contributor to this (culture, place, and identity/place attachments)

We provide sample indicators for each domain and dimension in Appendix 1. We present these, not as a definitive or universal list, but as a potential tool or starting point for communities, Tribes, agencies, and other entities to draw on in efforts to develop more locally or culturally relevant metrics.

Some indicators cut across multiple domains, and function as multidimensional measures rather than neatly bounded single dimension categories. For example, the indicator "change in the number of fish camps" was identified as a priority indicator for the Yukon and Kuskokwim regions. The Orutsararmiut Native Council has been collecting data for this indicator through surveys with Bethel area fish camps since 2001. This indicator cross-cuts domains of social relationships, environment, economy, voice and agency, and governance. In the context of the Upper Copper River region, the indicator "change in the number of working fish wheels" is representative of the cumulative effects of physical changes in the river system that have displaced suitable fish wheel sites, the financial cost of constructing new sites (including in some cases new road construction), land ownership and permissions (e.g., approval from the Bureau of Indian Affairs to construct roads across Native allotment lands held in trust), and family/social resources and needs, among others. Other multidimensional indicators include "proportion of new entrants in commercial salmon fisheries by age and residency," "percentage of residents who agree they have input into resource management decisions," and "number of households harvesting, giving, and receiving salmon for subsistence."

Multidimensional indicators are candidates as priority indicators because they capture trends and dynamics reflective of multiple stressors or drivers of change affecting salmon-human connections in Alaska. We highlight them here as examples of priority indicators for specific regions of Alaska.

Case study: the Upper Copper River

Few indicators reviewed by our team were universally applicable across Alaska's diverse salmon fisheries, cultures, and communities. Important differences also emerged in how individuals in our working group prioritized domains and indicators. We found that even among our highest ranked indicators, the need for local grounding was essential. For example, although "total pounds of salmon harvested for subsistence uses" and "number of households harvesting salmon for subsistence uses" were high ranking indicators and suitable for many communities and regions, they were inadequate measures for places like the Upper Copper River without close attention to scale and specific social groups.

The Upper Copper River is home to eight traditional Ahtna villages with well-documented social, economic, spiritual, and cultural connections to salmon (Simeone and Kari 2002, Simeone 
and McCall Valentine 2007; Native Perspectives on Sustainability project interview with W. Justin 2007, https://www. nativeperspectives.net/Leaders W Justin.php). ${ }^{[4]}$ The Copper River Basin is one of the few subsistence areas in the state that is on the road system, which has opened the area up to Alaska's urban population. As a result, it is a site of continuing conflict and pressure on salmon populations.

Today more than $75 \%$ of the subsistence salmon harvest in the Glennallen subdistrict of the Upper Copper River is taken by nonlocals (Fig. 3). In Figure 4 we present data showing how relying only on local or total pounds harvested (the blue and orange lines), though both high ranking indicators, eclipses an essential indicator (the black line) for understanding trends and impacts on local subsistence harvesters and communities. Figure 5 shows similar trends but in the context of the indicator "number of subsistence salmon permits issued."

Fig. 3. Local and nonlocal subsistence salmon harvest levels for Glennallen subdistrict (as percentage of harvest).

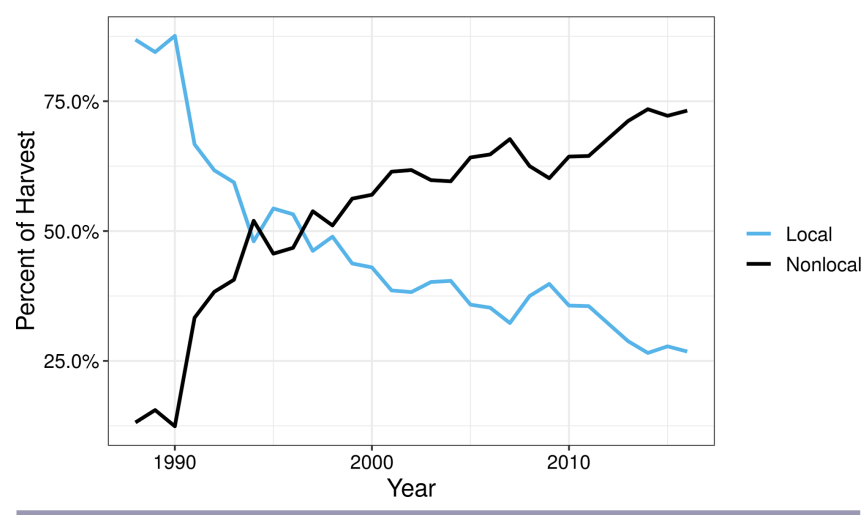

Fig. 4. Local, nonlocal, and total salmon harvest for Glennallen subdistrict (in number of fish).

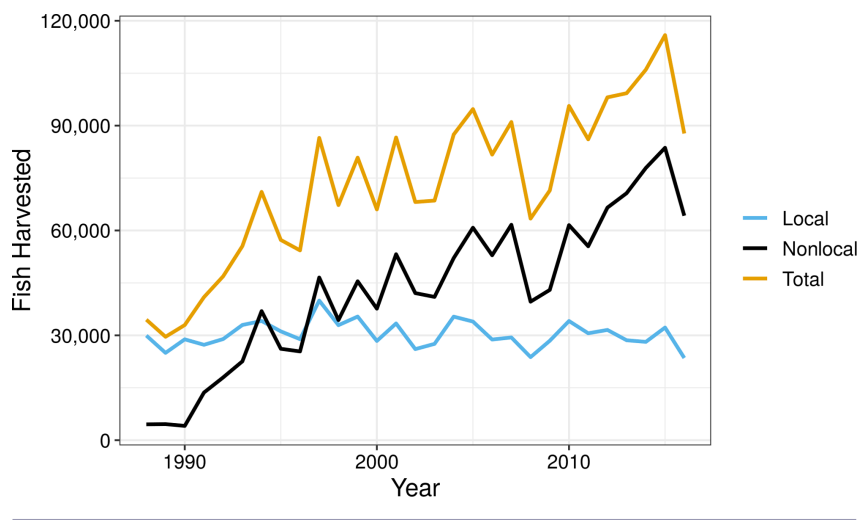

We present this example to (1) show how misleading indicators can be without proper context, and (2) highlight the importance of considering spatial scale in designing indicator-based wellbeing studies, and engaging communities from the outset in processes of indicator development and selection (Donatuto et al. 2011, Sterling et al. 2017). For example, data shown in Figures 3-5 represent subdistrict-level data only. Subdistrict data capture trends might be missed at smaller scales like community or household-level data, but in this case they exclude data for the neighboring Chitina subdistrict that also directly impacts subsistence fisheries in the Copper River Basin. ${ }^{[5]}$ More than $98 \%$ of the fishery participants in the Chitina subdistrict personal use fishery are nonlocal (Fall et al. 2014).

Fig. 5. Local, nonlocal, and total number of subsistence permits issued for Glennallen subdistrict.

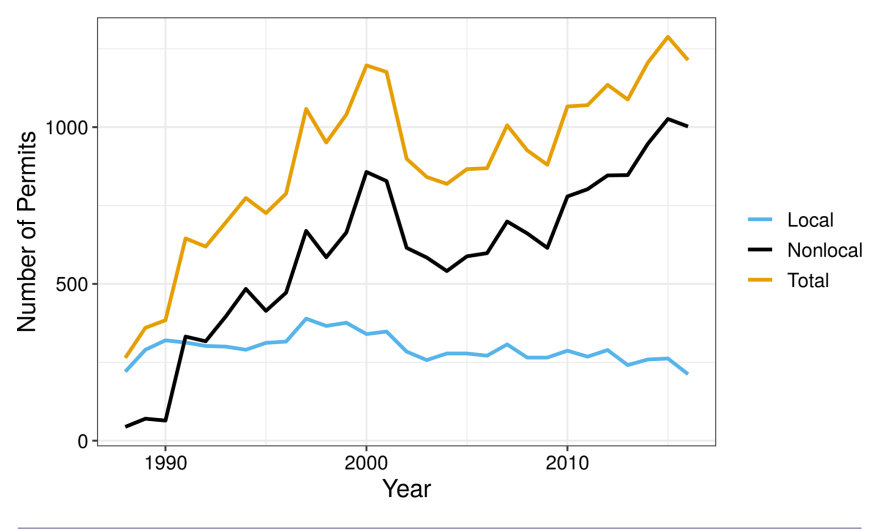

On the other hand, aggregated data can sometimes obscure locallevel and community-specific trends and issues. This is a particular risk in cases common to rural Alaska where aggregated data can be dominated by one large hub community at the expense of smaller villages. For example, Figure 6 shows that in 2017 the number of fish wheel permits returned to Alaska Department of Fish and Game (ADF\&G) by residents of the Copper River Basin hit a low $(n=200)$. The decline was not significant compared to years prior, but there was considerable variability among local communities (see Fig. 7). Thus, we caution against developing indicators in isolation of communities and groups under study. Moreover, we suggest that indicators are not a simple substitute for contextual information and careful qualitative research (see also Clay and Olson 2008, Charnley et al. 2017).

Fig. 6. Number of fish wheel permits returned by local/ nonlocal residency, 1988-2016.

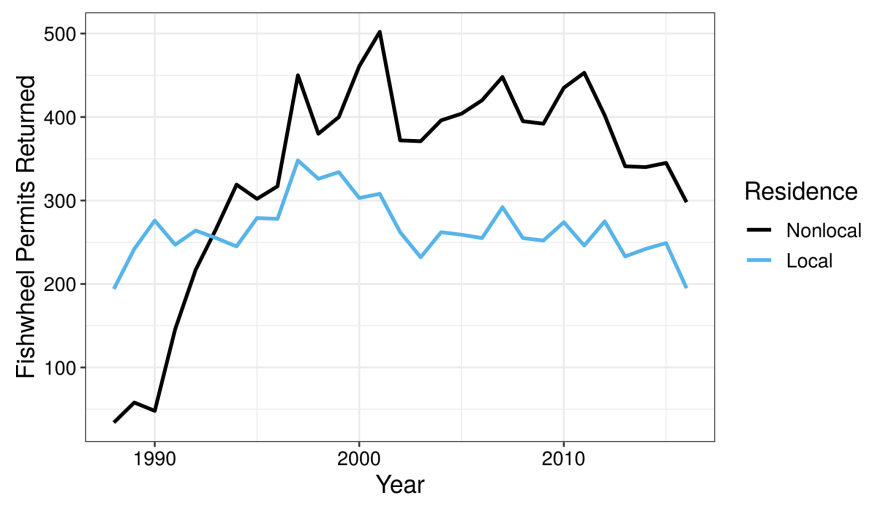

Data availability and limitations

Many of the indicators identified by our team as high priority do not have available data or the data have not been consistently measured. This was especially the case for small villages and for 
subsistence data where data collection in previous decades is frequently sparse. Data gaps also exist for nearly all subjective and relational indicators around quality of life and work; community and management satisfaction; many dimensions of resource access; entire domains such as voice and agency; culture, place, and identity; and social relationships. Because the policy arena tends to drive data collection and needs, some of the domains are underrepresented in the data used for policy decisions, while others are presented in isolation as if they represent well-being in its entirety, e.g., economy or environment, despite differences among groups subsumed by aggregated data.

Fig. 7. Change in number of fish wheel permits returned by community, 1988-2016.

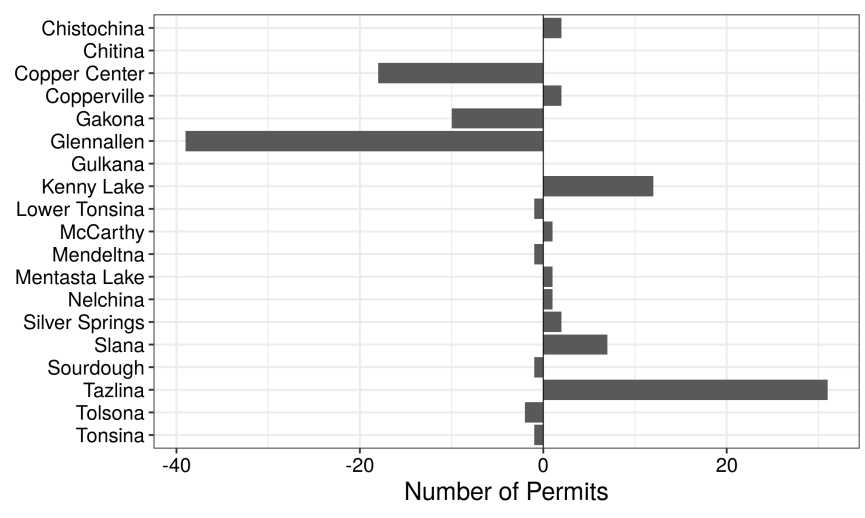

Our workgroup found that even in cases where data are regularly collected, they were difficult to obtain or, when available, not always taken into account in management decisions. One example of this is data on age distribution of permit holders collected by the Commercial Fisheries Entry Commission (CFEC), which shows a sharp decline in intergenerational access in commercial salmon fisheries. Since 1980, the median age of salmon permit holders in the state has increased from 40 to 54 years (CFEC 2018). ${ }^{[6]}$ Some regions, like Bristol Bay, have experienced a $50 \%$ decline in the number of permit holders under the age of 40 (Donkersloot and Carothers 2016). Despite expressed concern for such trends by state and fishery leaders and decision makers, ${ }^{[7]}$ recent management changes in some salmon fisheries have increased barriers to entry for the next generation of rural and Alaskan resident fishermen. Examples include allowing dual permit operations in the Bristol Bay drift fleet, which has proven to largely favor nonresident new entrants (see CFEC 2012 for similar outcomes related to permit stacking in Bristol Bay setnet fishery; M. Gho 2019, unpublished manuscript), and the most recent buyback program for the Southeast Alaska purse seine salmon fleet. ${ }^{[8]}$ The omission or marginalization of this information in decision making reflects not a lack of data, but a failure to meaningfully consider or prioritize intergenerational, rural, or Alaskan access as important to the sustainable management of Alaska salmon fisheries.

\section{Alaska state salmon management and well-being}

Here, we briefly review the inclusion and/or absence of well-being concepts in salmon management and evaluate their actual application in measuring state management goals and outcomes. ADF\&G's mission statement makes explicit reference to wellbeing:
To protect, maintain, and improve the fish, game, and aquatic plant resources of the state, and manage their use and development in the best interest of the economy and the well-being of the people of the state, consistent with the sustained yield principle. https://www.adfg. alaska.gov/index.cfm?adfg=about.mission

$\mathrm{ADF} \& \mathrm{G}$ advances this mission by ensuring "stable or increasing economic and social benefits derived from [fisheries] in Alaska." [9] The state currently measures the health of Alaska salmon systems by a set of criteria collected and evaluated by ADF\&G through key performance indicators. Key performance indicators include, but are not limited to, salmon escapement numbers, exvessel values (for commercial fisheries), and whether the amount necessary for subsistence (ANS) is achieved in subsistence fisheries. ${ }^{[10]}$

ADF\&G evaluates successful management of commercial fisheries with the metric, "Maintain total annual value of commercial harvests at over \$1 billion annually."[11] Although largely successful in achieving this annual economic target, this single performance indicator fails to consider the distribution of fishery benefits, including how and where salmon management generates economic and social benefits for the people of the state.

In the case of subsistence, both state and federal laws, e.g., the Alaska National Interest Lands Conservation Act (ANILCA), ${ }^{[12]}$ establish subsistence as a priority use (above commercial and sport/recreational interests) and acknowledge its economic, nutritional, social, and cultural importance (see also Thornton 1998). Subsistence uses of salmon are defined as "noncommercial, customary and traditional uses" (Fall et al. 2018:1). Although this definition implicitly references the customary and traditional hunting and fishing practices of Alaska Native peoples, any Alaskan resident may participate in subsistence fisheries (AK Statute 16.05.258; 16.05.940(34)). ${ }^{[13]}$ Thornton (1998) further explains:

\section{Federal and state laws do not define the term subsistence directly, only the phrase 'subsistence uses.' But ANILCA distinguishes Native subsistence as something exceptional and cultural, noting that "the opportunity for subsistence uses by rural residents of Alaska... is essential to Native physical, economic, traditional, and cultural existence and to non-Native physical, economic, traditional, and social existence." Although the distinction seems minor, it betrays a deeper philosophical division between Native and non-Native conceptions of subsistence. Alaska Natives typically define subsistence more fundamentally than non-Natives. For most Natives, subsistence is synonymous with culture, identity, and self-determination.}

Both state and federal management systems define subsistence uses with a set of socio-cultural and economic criteria. ${ }^{[14]}$ In these ways, social dimensions and goals are not wholly absent from salmon management and governance, but neither are they adequately tracked or evaluated. For example, ADF\&G tracks the performance indicator: "Achieve the Amount Necessary for Subsistence (ANS) established by the Board of Fisheries in 70\% of subsistence fisheries." ${ }^{[15]}$

The ANS was established in regulation as a range (in number of fish) identified by the Board of Fisheries as providing "reasonable opportunities" for subsistence uses to take place (Fall et al. 2014). 
Harvest data are regularly collected that can be annually compared to the ANS range. These data have been used as important indicators in recent years, especially in the Yukon and Kuskokwim regions where low Chinook salmon returns since 2008 have resulted in fishery closures and multiyear failure to achieve ANS. Fishery closures and restrictions have created serious hardship for Indigenous households and communities highly dependent on subsistence salmon harvests (see, for example, Fall et al. 2018, Black and Stevens 2019; Carothers, Black, Langdon, et al., unpublished manuscript). Our review of data suggests that in many subsistence fisheries ANS is not being met. For example, between 2001 and 2016, for the subset of fisheries evaluated, ADF\&G's target of achieving 70\% has only been met once. ${ }^{[16]}$

In our case study of the Upper Copper River, we found that in recent years, ANS has not been met in sections of the Glennallen subdistrict and where it has been met (such as in the lower section of the river), it is because of increasing participation from nonlocal harvesters (see Fig. 8). This raises questions about the utility of ANS as a measure that can adequately assess whether subsistence needs are being met in Indigenous communities in the Upper Copper River Basin where a growing number of urban Alaskans harvest salmon for subsistence. Despite being established in regulation in the 1990s (and revised in the 2000s), ${ }^{[17]}$ data on ANS in the Glennallen subdistrict was only available from 2011 to 2015. This was because harvest data had not been organized or analyzed by the three sections within the subdistrict, i.e., lower, middle, and upper sections of the river. During our attempts to access the Glennallen data, we learned that there is no systematic review of ANS numbers conducted by the state, and that the Glennallen subdistrict ANS values have never been reviewed or analyzed. Instead, ADF\&G relies on stakeholder input to voice concerns that prompt review of ANS data.

Fig. 8. Harvest and amount necessary for subsistence (ANS) levels (shown as black line) for Glennallen subdistrict river sections (lower, middle, and upper) by community residency, 2011-2015.

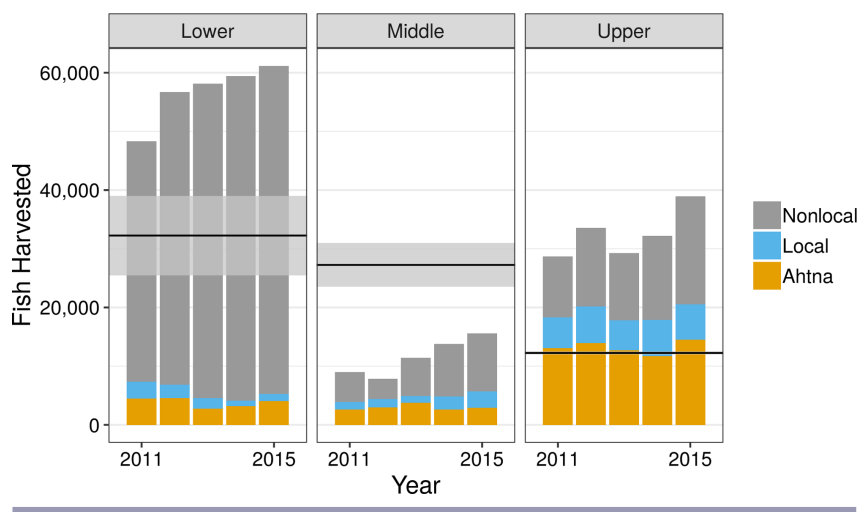

Similar to the indicator of total economic value discussed above, we identify ANS as a crude measure for whether subsistence needs are being met. For one, ANS operates under the assumption that a fishery system is working well when ANS numbers are in range. Further, the importance of ANS as an indicator is predicated on the number (in range of fish) being defined appropriately. For another, ANS is evaluated at the fishery level. Typically, the state does not analyze ANS data by residence of harvester. In this way, state data collection and categorization renders invisible the impacts of salmon management to certain groups of users, such as in our case study of Alaska Native communities and families. This may not be an issue for some subsistence fisheries in the state, but in regions like the Upper Copper River, it is especially problematic.

\section{DISCUSSION}

$A D F \& G$ performance indicators discussed above are examples of the ways in which state salmon management accounts for the social dimensions of fisheries. More broadly, these indicators represent the ways in which commercial and subsistence fisheries are understood to contribute to well-being in Alaska, e.g., economic value and food security. ${ }^{[18]}$ How might salmon management be improved if management goals, data collection, and decision making better accounted for the distribution of benefits and harms, including to future generations of Alaskans? This requires acknowledging equity as integral to sustainable salmon management.

Of the many well-being concepts identified and discussed by our workgroup, equity emerged as a fundamental and cross-cutting concept. How equitable is the distribution of access rights or opportunity to harvest? How equitably are people able to avail themselves of access opportunities? Whose views and ways of knowing are accepted and seen to have value when there are a diversity of views?

Many of the well-being indicators reviewed by our working group were equity-based indicators, including change in age structure of fishery; change in local and nonlocal permit holdings; change in Alaska Native permit holdings; value of access rights compared to median household income by community; diversity of users compared to diversity of managers; cost or time spent participating in management processes, e.g., understanding the processes or attending meetings; and percentage of residents who agree they have input in resource management and development decisions.

Of these, the State of Alaska currently collects data for the first two focused on age and residency of commercial fishery permit holders. These data show inequities in access to salmon, but too little progress has been made to date in addressing these trends. This is in part because equality-based policy measures guiding resource use and access in Alaska seek to treat individuals and groups of people the same. In reality, people are not the same. Not all people begin with common positions of power or shared capacities to equally enjoy the benefits of public resources, goods, and services; nor do they all have equal needs. Equality is the guiding principle of resource governance in Alaska, but this principle is often at odds with the principle of equity. ${ }^{[19]}$ Equity as a principle considers how distribution of resources and environmental threats, as well as procedural and distributive justice and access, are fundamentally shaped by social power, capital, geography, and demographic conditions (Hicks et al 2016). Equity-based measures also consider the distribution of resources and ability to participate in governance across generations.

Looking specifically at the impacts of equality-based measures on Indigenous peoples, Morrow and Hensel (1992) describe how an argument based on equal treatment of individuals under the 
law becomes an impediment to Indigenous rights and ways of life. Taylor (2008) further suggests that Indigenous affairs policy should focus less on achieving equality of socioeconomic status and more on facilitating choice and self-determination. The sustainability of Alaska salmon systems must be assessed through a framework that accounts for equity. Equality erases historical and current inequities, ranging from historical traumas rooted in colonization to contemporary disparities in health, justice, economic opportunity, and resource access. This erasure continues to harm rural and Alaska Native peoples, their livelihoods, and life ways (see, for example, Simeone and Kari 2002, McIvor et al. 2009, Viboud et al. 2013, Reedy and Maschner 2014, Carothers 2015, Langdon 2015, Alaska Native Epidemiology Center 2017, Black 2017). In the specific context of Alaska salmon systems, these impacts and inequities are seen in declining access to the resource; but more often, they are invisible, eclipsed by equality, and largely absent from current data collection efforts and fishery sustainability concerns as framed in the policy arena.

Our work exposes large gaps and limitations in data availability for many well-being domains and indicators in the context of Alaska salmon systems. Examples drawn on here show the risks associated with relying on indicators without appropriate context or cultural grounding. In multiple cases, we discovered how easy it is to misinterpret trends with indicators alone, or indicators applied at inappropriate scales. Indicators, like any tool, have limits. When qualities of well-being are translated into and treated as quantities of well-being, well-being risks being abstracted and reduced to simplistic measures (Satterfield et al. 2013, Amberson et al. 2016). Some aspects of well-being should not and cannot be reduced to quantifiable terms favored by economics (Son 2011). It should be for communities and groups affected by management and policy decisions to decide and guide what aspects of their lives and livelihoods can be reduced to the data points and decipherable terms preferred in Western science, management, and policy realms.

Our review and evaluation of well-being indicators makes a clear case for the value of qualitative social science research and careful, community-based ethnography (Clay and Olson 2008, FienupRiordan et al. 2013). Well-being indicators can add vital context to fisheries management systems that frequently approach humans as simplistic constructions of individualized profitmaximizing actors (Ostrom 1998, Pálsson 1991, Read 2009, Coleman 2019). But indicators can also obscure context. We present our indicator work here with a note of caution that direct community involvement and evaluation is the most effective and appropriate way to assess the well-being of people and communities. Attempts to measure well-being through simplified quantitative and qualitative indicators will only get so far. There are many indicator-based approaches yet to be pursued in Alaska and globally, but in-depth qualitative assessments will always be necessary for more fully understanding social-ecological relationships and human well-being. That being said, global efforts to date provide insightful direction for work in Alaska. Although there is broad consensus that well-being should be at the center of policy and decision making globally, attempts to address gaps and incorporate well-being measures in Alaska remain inadequate. The State of Alaska must begin with an inclusive, collaborative, and forward-thinking effort to refine and improve salmon management goals and identify additional metrics that capture what matters to people, and contributes to their well-being. These new measures must reflect the distribution of fishing opportunity and benefits.

\section{CONCLUSION}

We assess the sustainability and equity of Alaska salmon systems through a well-being framework that considers community and culturally defined concepts of human well-being. As part of this effort, we assess a range of indicators, and discuss their utility, limitations, and appropriateness as assessment tools that can effectively measure and evaluate social considerations within fishery systems.

One of the challenges facing fishery scientists and decision makers in Alaska today is how to integrate and operationalize human well-being concepts to improve management decisions and data collection. To date, the uptake of human well-being as a management objective has primarily occurred at the federal level in the context of ecosystem-based fishery management. Greater attention to the social sustainability of Alaska salmon systems by fishery scientists and decision makers at the state level will bring dimensions of well-being into the framework of sustainable fisheries management. This will require investing in social science, Indigenous peoples and their knowledge, and other expertise that can appropriately account for the social and cultural dimensions of fisheries and decision making. The meaningful inclusion of knowledge, values, and ways of knowing that are frequently excluded or marginalized in science and policy realms is critical. Indigenous expertise and knowledge in particular have formative and original roles to play in identifying and answering pressing sustainability questions, as well as those we have not yet formed. That said, inclusion of Indigenous and traditional knowledge challenges the entrenched principle of equality. The centrality of equal access in the state constitution and subsequent resource management decisions in Alaska is a contemporary rendition of the colonial structure that has systematically produced and obscured deep and lasting inequities in Alaska salmon systems. Salmon conservation and sustainability concerns are becoming increasingly prominent in Alaska as environmental change, nonrenewable resource development, and state budget shortfalls threaten and affect fisheries, food security, and cultural practices of great consequence to rural and Alaska Native livelihoods and communities. The solutions to these challenges must acknowledge the disproportionate impact borne by some, and be informed by social, cultural and community values, needs, and data to a degree not yet met. Accounting for these differences and dimensions is for ensuring "the well-being of the people of the state."

\footnotetext{
${ }^{[1]}$ See, for example, Appendix to the Congressional Record A4953, A New Day for Alaska Natives, Remarks by Honorable E.L. Bartlett, 8 August 1951, which describes colonizing efforts to address the "subsistence problem" by bringing educating and relocating Alaska Natives into the "American way of life" and "white man's economy."

[2] Note also that traditional hunting and fishing livelihoods (called subsistence in Alaska) are not given consideration in state planning. As Wolfe and Walker (1987:68) explain: "Subsistence uses have an ambiguous status in regard to other uses of public lands. Subsistence is not recognized as a separate type of land use
} 
in state land planning classifications of the state's Department of Natural Resources, charged with managing state lands. While a variety of land uses are recognized (agriculture, coal, forest, geothermal, grazing, heritage resources, material, mineral, oil and gas, public recreation, reserved, resource management, settlement, transportation corridor, water resources, and wildlife habitat), subsistence fishing and hunting for food is not. Consequently, ongoing subsistence uses receive no protection in legislation or regulation in the development of state lands. As the state creates plans for the future use and development of state land holdings to "provide for balanced use, development, and conservation of those resources for the maximum benefit of the people of Alaska... [and to] identify primary uses" (Alaska Administrative Code 55.010), there is no requirement for these new uses to be assessed for their impacts on ongoing subsistence activities."

${ }^{[3]}$ Federal and state laws guide salmon management in Alaska. We focus primarily on state management and governance systems. The State of Alaska manages commercial salmon fisheries in Alaska under the authority of the Board of Fisheries. Subsistence fisheries are governed by a dual federal and state management system. The Alaska National Interest Lands Conservation Act (ANILCA) passed by the U.S. Congress in 1980, applies to federal lands in Alaska and serves as the counterpart to state subsistence law. The primary difference between state and federal subsistence law is who qualifies for participation in subsistence fisheries. Under federal law, only rural Alaska residents qualify for subsistence harvesting. Since 1989, all Alaska residents have qualified under state law.

${ }^{[4]}$ The Ahtna are an Athabascan speaking people who live in the Copper River Basin (Simeone and Kari 2002).

[5] The Chitina district is a personal use fishery. Personal use fisheries differ from sport and subsistence fisheries in Alaska. The Board of Fisheries established personal use fisheries to allow Alaskan residents to harvest fish for food in nonsubsistence areas in the state, e.g., where dependence upon subsistence (customary and traditional uses of fish and wildlife) is not a principal characteristic of the economy, culture, and way of life (AS 16.05.258(c)).

${ }^{[6]}$ This age increase is specific to Alaska resident salmon fishermen only and does not include nonresidents of the state that hold permits in Alaska salmon fisheries.

${ }^{[7]}$ See, for example, HCR State of Alaska, "HCR18-Commercial Fisheries Programs,” 2012, http://www.akleg.gov/basis/Bill/ Detail/27?Root=HCR\%2018\#tab1 4.

${ }^{[8]}$ The buyback was approved in early 2019 despite concerns from the State of Alaska, including increasing barriers to entry. See ADF\&G Comments on the Public Notice on the Fishing Capacity Reduction Program for the Southeast Alaska Purse Seine Salmon Fishery. FR Vo. 81, No. 215 / Monday, 7 November 2016. 78123-78129.

[9] See https://www.omb.alaska.gov//html/performance/details. html?p=60\#td4502

${ }^{[10]}$ There are additional performance measures for sport and recreational fisheries, funding, and research, etc. See https://omb. alaska.gov/html/performance/program-indicators. html? $\mathrm{p}=55 \& \mathrm{r}=1$ ${ }^{[11]}$ See https://www.omb.alaska.gov//html/performance/details. html? $\mathrm{p}=60 \# \mathrm{td} 4502$

${ }^{[12]}$ Title 8 of ANILCA ensures the continuation of subsistence uses on public lands by rural Alaska Natives and non-Natives.
ANILCA was meant to address a fundamental problem with the Alaska Native Claims Settlement Act (ANCSA) of 1971: the extinguishment of Alaska Native hunting and fishing rights. For many Alaska Native leaders and subsistence harvesters, ANILCA's rural residency preference remains a promise undelivered.

${ }^{[13]}$ See http://www.adfg.alaska.gov/techpap/tp406.pdf

${ }^{[14]} \mathrm{https}$ //www.adfg.alaska.gov/index.cfm?adfg=subsistence.customary

[15] See https://omb.alaska.gov/html/performance/details.html? $\mathrm{p}=60$

${ }^{[16]}$ Note that the dataset used to evaluate this indicator includes only a subset of subsistence fisheries in the state. It is unclear how subsistence fisheries were selected to be included in evaluating this performance indicator.

${ }^{[17]}$ The current ANS was recommended to the Board of Fisheries by $A D F \& G$ in the 2000 s, replacing an earlier ANS that was for the entire river. The current ANS divides the Glennallen subdistrict of the Upper Copper River into three sections and was recommended based on a review of fishing patterns and other factors.

${ }^{[18]}$ Food security at the community level is not monitored annually; however, the Division of Subsistence has administered a modified version of the USDA food security questionnaire in over 100 Alaska communities since 2003.

${ }^{[19]}$ We focus primarily on state law in this discussion, but recognize that federal laws also pose legal hurdles. For example, the Alaska Native Claims Settlement Act extinguished aboriginal hunting and fishing rights (see Thornton 1998, Tuck 2014, Anderson 2016, 2018).

Responses to this article can be read online at: http://www.ecologyandsociety.org/issues/responses. php/11549

\section{Acknowledgments:}

We thank SASAP Project PIs, Ian Dutton and Frank Davis, for their vision and oversight of the entire $S A S A P$ process and project. We also thank Nautilus staff Sarah Warnock and Katherine Schake for their efforts and logistical support throughout the project. A huge thanks goes to NCEAS staff, especially Jeanette Clark and Ginger Gillquist, but also Matt Jones, Jared Kibele, Jenny Seifert, and Robyn Thiessenbock. We thank the University of Alaska Fairbanks graduate students, January Scott and Brooke Woods, for their work on this project. We thank Zack Martin for his artistic abilities and help in bringing this work to life through art and inspiration. You can view and interact with a digitized depiction of Zack's work at https:/lalaskasalmonandpeople.org/topics/wellbeing-and-salmon-systemsl. We thank Marcus Gho, Jennifer Shriver, and David Koster for their grasp of data drawn on in this work and willingness to answer so many of our questions. Finally, we thank two anonymous reviewers for their helpful comments that have helped to improve this manuscript greatly.

\section{Data Availability Statement:}

The data that support the findings of this study are available at the Knowledge Network for Biocomplexity (KNB) https://knb. 
ecoinformatics.orgl. As noted in the manuscript, these data were derived from the following resources available in the public domain: Alaska Department of Fish and Game, Commercial Fisheries Entry Commission, and the U.S. Census Bureau.

\section{LITERATURE CITED}

Adelson, N. 2000. 'Being alive well': health and the politics of Cree well-being. University of Toronto Press, Toronto, Ontario, Canada. [online] URL: http://www.jstor.org/stable/10.3138/j. $\underline{\mathrm{ctt} 1287 \mathrm{z} 00}$

Alaska Native Epidemiology Center. 2017. Statewide data life expectancy. Alaska Native Tribal Health Consortium, Anchorage, Alaska, USA. [online] URL: http://anthctoday.org/ epicenter/healthData/factsheets/Life_Expectancy_statewide_2_1_2017. pdf

Amberson, S., K. Biedenweg, J. James, and P. Christie. 2016. "The heartbeat of our people": identifying and measuring how salmon influences Quinault tribal well-being. Society and Natural Resources 29(12):1389-1404. https://doi.org/10.1080/08941920.2016.1180727

Anderson, R. T. 2016. Sovereignty and subsistence: Native selfgovernment and rights to hunt, fish, and gather after ANCSA. Alaska Law Review 33:187-227. [online] URL: https:// scholarship.law.duke.edu/alr/vol33/iss2/3

Anderson, R. 2018. The Katie John Litigation: a continuing search for Alaska Native fishing rights after ANCSA. Arizona State Law Journal 51:845-877.

Apgar-Kurtz, B. 2015. Factors affecting local permit ownership in Bristol Bay. Marine Policy 56:71-77. https://doi.org/10.1016/j. marpol.2015.02.013

Armitage, D., C. Béné, A. T. Charles, D. Johnson, and E. H. Allison. 2012. The interplay of well-being and resilience in applying a social-ecological perspective. Ecology and Society 17 (4):15. http://dx.doi.org/10.5751/ES-04940-170415

Bernard, H. R. 2018. Research methods in anthropology: qualitative and quantitative approaches. Sixth edition. Rowman and Littlefield, Lanham, Maryland, USA.

Biedenweg, K. 2014. Recommended social indicators for Puget Sound Partnership: a report summarizing findings from three local case studies. Puget Sound Institute, University of Washington, Tacoma, Washington, USA.

Black, J. C. 2017. Participation in governance and well-being in the Yukon Flats. Dissertation. Washington University in St. Louis, St. Louis, Missouri, USA. [online] URL: https://openscholarship. wustl.edu/art_sci_etds/1270

Black, J., and C. Stevens. 2019. I am a criminal: criminalization of Indigenous fishing practices. The State of Alaska Salmon and People Project, Alaska, USA.

Boraas, A. S., and C. H. Knott. 2013. Traditional ecological knowledge and characterization of the Indigenous cultures of the Nushagak and Kvichak watersheds, Alaska. Appendix D in $A n$ assessment of potential mining impacts on salmon ecosystems of Bristol Bay, Alaska. U.S. Environmental Protection Agency. [online] URL: https://www.epa.gov/sites/production/files/2015-05/ documents/bristol bay assessment final 2014 vol2.pdf
Braund, S. R. 2017. Social indicators in Coastal Alaska: Arctic communities, final report. Technical Report No. BOEM 2017-035. Prepared for the U.S. Department of the Interior, Alaska OCS Region. Braund \& Associates, Anchorage, Alaska, USA.

Breslow, S. J. 2015. Accounting for neoliberalism: "social drivers" in environmental management. Marine Policy 61:420-429. https:// doi.org/10/gd53kd

Breslow, S. J., M. Allen, D. Holstein, B. Sojka, R. Barnea, X. Basurto, C. Carothers, S. Charnley, S. Coulthard, N. Dolšak. J. Donatuto, C. García-Quijano, C. C. Hicks, A. Levine, M. B. Mascia, K. Norman, M. Poe, T. Satterfield, K. St. Martin, and P. S. Levin. 2017. Evaluating indicators of human well-being for ecosystem-based management. Ecosystem Health and Sustainability 3(12):1-18. https://doi.org/10/gd53kh

Breslow, S. J., B. Sojka, R. Barnea, X. Basurto, C. Carothers, S. Charnley, S. Coulthard, N. Dolšak, J. Donatuto, C. GarcíaQuijano, C. C. Hicks, A. Levine, M. B. Mascia, K. Norman, M. Poe, T. Satterfield, K. St. Martin, and P. S. Levin. 2016. Conceptualizing and operationalizing human wellbeing for ecosystem assessment and management. Environmental Science \& Policy 66:250-259. https://doi.org/10/f9dgdd

Carothers, C. 2011. Equity and access to fishing rights: exploring the community quota program in the Gulf of Alaska. Human Organization 70(3):213-223. https://doi.org/10/gd53kt

Carothers, C. 2015. Fisheries privatization, social transitions, and well-being in Kodiak, Alaska. Marine Policy 61:313-322. http:// dx.doi.org/10.1016/j.marpol.2014.11.019

Charnley, S., C. Carothers, T. Satterfield, A. Levine, M. R. Poe, K. Norman, J. Donatuto, S. J. Breslow, M. B. Mascia, P. S. Levin, X. Basurto, C. C. Hicks, C. García-Quijano, and K. St. Martin. 2017. Evaluating the best available social science for natural resource management decision-making. Environmental Science \& Policy 73:80-88. https://doi.org/10.1016/j.envsci.2017.04.002

Clay, P. M., A. Kitts, and P. Pinto da Silva. 2014. Measuring the social and economic performance of catch share programs: definition of metrics and application to the U.S. Northeast Region groundfish fishery. Marine Policy 44:27-36. https://doi. org/10.1016/j.marpol.2013.08.009

Clay, P. M., and J. Olson. 2008. Defining "fishing communities": vulnerability and the Magnuson-Stevens fishery conservation and management act. Human Ecology Review 15(2):143-160.

Colburn, L. L., M. Jepson, C. Weng, T. Seara, J. Weiss, and J. A. Hare. 2016. Indicators of climate change and social vulnerability in fishing dependent communities along the Eastern and Gulf Coasts of the United States. Marine Policy 74:323-333. https:// doi.org/10.1016/j.marpol.2016.04.030

Coleman, J. M. 2019. Commercial fishing livelihoods, permit loss, and the next generation in Bristol Bay, Alaska. Dissertation. University of Alaska Fairbanks, Fairbanks, Alaska, USA.

Coleman, J., C. Carothers, R. Donkersloot, D. Ringer, P. Cullenberg, and A. Bateman. 2018. Alaska's next generation of potential fishermen: a survey of youth attitudes towards fishing and community in Bristol Bay and the Kodiak Archipelago, Alaska. Maritime Studies 18:47-63. https://doi.org/10.1007/ s40152-018-0109-5 
Commercial Fisheries Entry Commission (CFEC). 2012. Bristol Bay set gillnet permit stacking. CFEC Report no. 12-02-N November 2012. CFEC, Juneau, Alaska, USA.

Commercial Fisheries Entry Commission (CFEC). 2018. Executive summary changes in the distribution of Alaska's commercial fisheries entry permits 1975-2017. CFEC Report Number 18-02N-EXEC. CFEC, Juneau, Alaska, USA.

Coulthard, S. 2012. What does the debate around social wellbeing have to offer sustainable fisheries? Current Opinion in Environmental Sustainability 4:358-363. https://doi.org/10.1016/ j.cosust.2012.06.001

Coulthard, S., D. Johnson, and J. A. McGregor. 2011. Poverty, sustainability and human wellbeing: a social wellbeing approach to the global fisheries crisis. Global Environmental Change 21 (2):453-463. https://doi.org/10/ftkn4s

Cullenberg, P., R. Donkersloot, C. Carothers, J. Coleman, and D. Ringer. 2017. Turning the tide: How can Alaska address the 'graying of the fleet' and loss of rural fisheries access? University of Alaska Fairbanks, Anchorage, Alaska, USA.

Donatuto, J., and M. R. Poe. 2015. Evaluating sense of place as a domain of human well-being for Puget Sound restoration. Technical report. University of Washington Puget Sound Institute, Tacoma, Washington, USA.

Donatuto, J. L., T. A. Satterfield, and R. Gregory. 2011. Poisoning the body to nourish the soul: prioritising health risks and impacts in a Native American community. Health, Risk and Society 13 (2):103-127. https://doi.org/10.1080/13698575.2011.556186

Donkersloot, R., and C. Carothers. 2016. The graying of the Alaskan fishing fleet. Environment: Science and Policy for Sustainable Development 58(3):30-42. http://dx.doi. org/10.1080/00139157.2016.1162011

Fall, J. A., N. M. Braem, C. L. Brown, S. S. Evans, L. HutchinsonScarbrough, H. Ikuta, B. Jones, R. La Vine, T. Lemons, M. A. Marchioni, E. Mikow, J. T. Ream, and L. A. Sill. 2014. Alaska subsistence and personal use salmon fisheries 2012 annual report. Technical Paper No. 406. Alaska Department of Fish and Game, Division of Subsistence, Anchorage, Alaska, USA. [online] URL: http://www.adfg.alaska.gov/techpap/tp406.pdf

Fall, J., A. Godduhn, G. Halas, L. Hutchinson-Scarbrough, B. Jones, E. Mikow, L. A. Sill, A. Trainor, A. Wiita, and T. Lemons. 2018. Alaska subsistence and personal use salmon fisheries 2015 annual report. Technical Paper No. 440. Alaska Department of Fish and Game, Division of Subsistence, Anchorage, Alaska, USA.

Fienup-Riordan, A., C. Brown, and N. M. Braem. 2013. The value of ethnography in times of change: the story of Emmonak. Deep Sea Research Part II: Topical Studies in Oceanography 94:301-311. https://doi.org/10/f5gbn9

Fienup-Riordan, A., and C. Moncrieff. 2017. King salmon on the Lower Yukon River-past and present: a Yupik language elders workshop. Yukon River Drainage Fisheries Association, Anchorage, Alaska, USA.

Food and Agriculture Organization of the United Nations (FAO). 2005. The state of food and agriculture. FAO, Rome, Italy.
García-Quijano, C. G., J. J. Poggie, A. Pitchon, and M. H. Del Pozo. 2015. Coastal resource foraging, life satisfaction, and wellbeing in southeastern Puerto Rico. Journal of Anthropological Research 71(2):145-167. https://doi.org/10/gd53m3

Harrison, G. 2018. Alaska's constitution. A citizen's guide. Fifth edition. Alaska Legislative Affairs Agency, Juneau, Alaska, USA. [online] URL: http://w3.legis.state.ak.us/docs/pdf/citizens guide. pdf

Hicks, C. C., A. Levine, A. Agrawal, X. Basurto, S. J. Breslow, C. Carothers, S. Charnley, S. Coulthard, N. Dolšak, J. Donatuto, C. Garcia-Quijano, M. B. Mascia, K. Norman, M. R. Poe, T. Satterfield, K. St. Martin, and P. S. Levin. 2016. Engage key social concepts for sustainability. Science 352(6281):38-40. https://doi. org/10/gc $3 f 7 h$

Inuit Circumpolar Council (ICC) Alaska. 2015. Alaskan Inuit food security conceptual framework: how to assess the Arctic from an Inuit perspective: summary report and recommendations report. Technical Report. Inuit Circumpolar Council-Alaska, Anchorage, Alaska, USA.

Jepson, M., and L. Colburn. 2013. Development of social indicators of fishing community vulnerability and resilience in the U.S. Southeast and Northeast regions. NOAA Technical Memorandum. National Oceanic and Atmospheric Administration, Silver Spring, Maryland, USA.

Kamali, N. 1984. Alaskan Natives and limited fisheries of Alaska: a study of changes in the distribution of permit ownership amongst Alaskan Natives, 1975-1983. Commercial Fisheries Entry Commission Report 84-8. CFEC, Juneau, Alaska, USA.

Koslow, A. 1986. Limited entry policy and impacts on Bristol Bay fishermen. Pages 47-62 in S. Langdon, editor. Contemporary Alaskan Native economies. University Press of America, Lanham, Maryland, USA.

Kovach, M. 2010. Indigenous methodologies. University of Toronto Press, Toronto, Ontario, Canada.

Krupa, M. B., M. McCarthy Cunfer, and J. Clark. 2019. Who's winning the public process? How to use public documents to assess the equity, efficiency, and effectiveness of stakeholder engagement. Society \& Natural Resources 33(5):612-633. https:// doi.org/10.1080/08941920.2019.1665763

Langdon, S. 1980. Transfer patterns in Alaskan limited entry fisheries. University of Alaska, Anchorage, Alaska, USA.

Langdon, S. 2015. Forgone harvests and neoliberal policies: creating opportunities for rural, small-scale, community-based fisheries in southern Alaskan coastal villages. Marine Policy 61:347-355. https://doi.org/10.1016/j.marpol.2015.03.007

Leong, K. M., S. Wongbusarakum, R. J. Ingram, A. Mawyer, and M. R. Poe. 2019. Improving representation of human well-being and cultural importance in conceptualizing the west Hawai'i ecosystem. Frontiers in Marine Science 6:213. https://doi. org/10.3389/fmars.2019.00231

McGregor, A. 2008. Well-being, poverty and conflict. Briefing Paper 1/08. Economic \& Social Research Council Research Group on Wellbeing in Developing Countries, University of Bath, Bath, UK. 
McIvor, O., A. Napoleon, and K. Dickie. 2009. Language and culture as protective factors for at-risk communities. Journal of Aboriginal Health November 2009:6-25.

Millennium Ecosystem Assessment (MEA). 2005. Ecosystems and human well-being: synthesis. Island, Washington, D.C., USA. [online] URL: http://www.millenniumassessment.org/documents/ document.356.aspx.pdf

Morrow, P., and C. Hensel. 1992. Hidden dissension: minoritymajority relationships and the use of contested terminology. Arctic Anthropology 29(1):38-53.

Ostrom, E. 1998. A behavioral approach to the rational choice theory of collective action: presidential address, American Political Science Association, 1997. American Political Science Review 92(1):1-22. https://doi.org/10.2307/2585925

Pálsson, G. 1991. Coastal economies, cultural accounts: human ecology and Icelandic discourse. Manchester University Press, Manchester, UK.

Pascual, U., P. Balvanera, S. Díaz, G. Pataki, E. Roth, M. Stenseke, R. T. Watson, E. Başak Dessane, M. Islar, E. Kelemen, V. Maris, M. Quaas, S. M. Subramanian, H. Wittmer, A. Adlan, S. Ahn, Y. S. Al-Hafedh, E. Amankwah, S. T. Asah, P. Berry, A. Bilgin, S. J. Breslow, C. Bullock, D. Cáceres, H. Daly-Hassen, E. Figueroa, C. D. Golden, E. Gómez-Baggethun, D. GonzálezJiménez, J. Houdet, H. Keune, R. Kumar, K. Ma, P. H. May, A. Mead, P. O'Farrell, R. Pandit, W. Pengue, R. Pichis-Madruga, F. Popa, S. Preston, D. Pacheco-Balanza, H. Saarikoski, B. B. Strassburg, M. van den Belt, M. Verma, F. Wickson, and N. Yagi. 2017. Valuing nature's contributions to people: the IPBES approach. Current Opinion in Environmental Sustainability 26-27:7-16. [online] URL: http://www.sciencedirect.com/science/ article/pii/S1877343517300040 https://doi.org/10.1016/j. cosust.2016.12.006

Petterson, J. S. 1983. Limited entry and the Native American fisherman: a case study of the Bristol Bay, Alaska salmon fishery. Report on File NSF Grant \# DAR-7917582. ADF\&G, Division of Subsistence, Anchorage, Alaska, USA.

Pitcher, T. J., M. E. Lam, C. Ainsworth, A. Martindale, K. Nakamura, R. I. Perry, and T. Ward. 2013. Improvements to rapfish: a rapid evaluation technique for fisheries integrating ecological and human dimensions. Journal of Fish Biology 83 (4):865-889. https://doi.org/10/gd53rd

Pitcher, T. J., and M. P. Power. 2000. Fish figures: quantifying the ethical status of Canadian fisheries, east and west. Pages 225-253 in H. Coward, R. Ommer, and T. J. Pitcher, editors. Just fish: the ethics of Canadian fisheries. Institute of Social and Economic Research Press, St John's, Newfoundland, Canada.

Poe, M. R., M. K. Watkinson, B. Trosin, and K. Decker. 2015. Social indicators for the Washington Coast Integrated Ecosystem Assessment. A Report to Washington Department of Natural Resources in fulfillment of Interagency Agreement No. IAA 14-204. Washington Sea Grant WSG-TR 15-07. Seattle, Washington, USA.

Pollnac, R., M. Bavinck, and I. Monnereau. 2012. Job satisfaction in fisheries compared. Social Indicators Research 109:119-133. https://doi.org/10.1007/s11205-012-0059-z
Pollnac, R. B., and J. J. Poggie. 2008. Happiness, well-being and psychocultural adaptation to the stresses associated with marine fishing. Human Ecology Review 15(2):194-200.

Poppel, B., J. Kruse, G. Duhaime, and L. Abryutina. 2007. SLiCA Results. vol. 2009. Institute of Social and Economic Research, University of Alaska, Anchorage, Alaska, USA.

Ragnarsdottir, K. V., and ASAP Team. 2014. Beyond GDP. Geoscientist Online 24(9):12-17. [online] URL: https://www. geolsoc.org.uk/Geoscientist/Archive/October-2014/Beyond-GDP

Raymond-Yakoubian, B., and J. Raymond-Yakoubian. 2015. Always taught not to waste: traditional knowledge and Norton Sound/Bering Strait salmon populations. Arctic-YukonKuskokwim Sustainable Salmon Initiative Project 1333 Final Product. Kawerak, Incorporated, Nome, Alaska, USA.

Raymond-Yakoubian, J. 2019. Salmon, cosmology, and identity in Elim, AK. Dissertation. University of Alaska, Fairbanks, Alaska, USA.

Raymond-Yakoubian, J., and R. Daniel. 2018. An Indigenous approach to ocean planning and policy in the Bering Strait region of Alaska. Marine Policy 97:101-108. https://doi.org/10.1016/j. marpol.2018.08.028

Raymond-Yakoubian, J., B. Raymond-Yakoubian, and C. Moncrieff. 2017. The incorporation of traditional knowledge into Alaska federal fisheries management. Marine Policy 78:132-142. https://doi.org/10.1016/j.marpol.2016.12.024

Read, J. 2009. A genealogy of homo-economicus: Neoliberalism and the production of subjectivity. Foucault Studies 6:25-36. http://dx.doi.org/10.22439/fs.v0i0.2465

Reedy, K., and H. Maschner. 2014. Traditional foods, corporate controls: networks of household access to key marine species in southern Bering Sea villages. Polar Record 50(4):364-378. https:// doi.org/10.1017/S0032247414000084

Ribot, J. C., and N. L. Peluso. 2003. A theory of access. Rural Sociology 68(2):153-181. https://doi.org/10.1111/j.1549-0831.2003. $\underline{\text { tb00133.x }}$

Ringer, D., C. Carothers, R. Donkersloot, J. Coleman, and P. Cullenberg. 2018. For generations to come? The privatization paradigm and shifting social baselines in Kodiak, Alaska's commercial fisheries. Marine Policy 98:97-103. https://doi. org/10.1016/j.marpol.2018.09.009

Ruby, A., and R. Heyano. 2016. Efforts to regain permits: successes and challenges in Bristol Bay. Pages 73-80 in P. Cullenberg, editor. Fisheries access for Alaska: charting the future. Workshop Proceedings. Alaska Sea Grant, University of Alaska Fairbanks, AK-SG-16-02, Fairbanks, Alaska, USA. http://doi. org/10.4027/faacfwp.2016

Satterfield, T., R. Gregory, S. Klain, M. Roberts, and K. M. Chan. 2013. Culture, intangibles and metrics in environmental management. Journal of Environmental Management 117:103-114. https://doi.org/10/f4srn8

Sen, A. 1999. Development as freedom. Anchor Books, New York, New York, USA. 
Sethi, S. A., W. Riggs, and G. Knapp. 2014. Metrics to monitor the status of fishing communities: an Alaska state of the state retrospective 1980-2010. Ocean \& Coastal Management 88:21-30. https://doi.org/10/gd53p5

Simeone, W. E., and J. Kari. 2002. Traditional knowledge and fishing practices of the Ahtna of the Copper River, Alaska. Technical Paper No. 270. Alaska Department of Fish and Game, Juneau, Alaska, USA.

Simeone, W., and E. McCall Valentine. 2007. Ahtna knowledge of long-term challenges in salmon runs in the Upper Copper River drainage, Alaska. Technical Paper No. 324. Alaska Department of Fish and Game, Division of Subsistence, Juneau, Alaska, USA.

Smith, C., and P. Clay. 2010. Measuring subjective and objective well-being: analyses from five marine commercial fisheries. Human Organization 69(2):158-168. https://doi.org/10.17730/ humo.69.2.b83x6t44878u4782

Son, H. H. 2011. Equity and well-being: measurement and policy practice. Routledge, London, UK. https://doi.org/10.4324/9780203155042

Song, A. M., H. Bodwitch, and J. Scholtens. 2018. Why marginality persists in a governable fishery - the case of New Zealand. Maritime Studies 17:285-293. https://doi.org/10.1007/ $\underline{\text { 440152-018-0121-9 }}$

Stariwat, J. 2016. Regulatory impacts on a Yup'ik fish camp in Southwest Alaska. Thesis. University of British Columbia, Vancouver, British Columbia, Canada.

Sterling, E. J., C. Filardi, A. Toomey, A. Sigouin, E. Betley, N. Gazit, J. Newell, S. Albert, D. Alvira, N. Bergamini, M. Blair, D. Boseto, K. Burrows, N. Bynum, S. Caillon, J. E. Caselle, J. Claudet, G. Cullman, R. Dacks, P. B. Eyzaguirre, S. Gray, J. Herrera, P. Kenilorea, K. Kinney, N. Kurashima, S. Macey, C. Malone, S. Mauli, J. McCarter, H. McMillen, P. Pascua, P. Pikacha, A. L. Porzecanski, P. de Robert, M. Salpeteur, M. Sirikolo, M. H. Stege, K. Stege, T. Ticktin, R. Vave, A. Wali, P. West, K. B. Winter, and S. D. Jupiter. 2017. Biocultural approaches to well-being and sustainability indicators across scales. Nature Ecology \& Evolution 1:1798-1806. https://doi.org/10.1038/s41559-017-0349-6

Stiglitz, J., J. Fitoussi, and M. Durand. 2018. Beyond GDP: measuring what counts for economic and social performance. OECD Publishing, Paris, France. [online] URL: https://doi. org/10.1787/9789264307292-en

Stiglitz, J., A. Sen, and J. P. Fitoussi. 2009. Report by the Commission on the Measurement of Economic Performance and Social Progress. Report formally commissioned by the French Government. [online] URL: https://www.researchgate.net/ publication/258260767 Report of the Commission on the Measurement_of_Economic_Performance_and_Social_Progress_CMEPSP

Strauss, A., and J. Corbin. 1990. Basics of qualitative research: grounded theory, procedures and techniques. SAGE, Newbury Park, California, USA.

Taylor, J. 2008. Indigenous peoples and indicators of well-being: Australian perspectives on United Nations global frameworks. Social Indicators Research 87:111-126. https://doi.org/10.1007/ $\underline{\text { s11205-007-9161-Z }}$
Thornton, T. F. 1998. Alaska Native subsistence: a matter of cultural survival. Cultural Survival Quarterly 22(3):29-34.

Tuck, E. 2014. Alaska Native Claims Settlement Act as X-Mark. Pages 241-270 in B. Leonard, J. Breinig, L. Carpluk, S. Lind, M. Williams, editors. Transforming the university: Alaska Native studies in the 21st century. Two Harbors Press, Minneapolis, Minnesota, USA.

Viboud, C., J. Eisenstein, A. H. Reid, T. A. Janczewski, D. M. Morens, and J. K. Taubenberger. 2013. Age- and sex-specific mortality associated with the 1918-1919 influenza pandemic in Kentucky. Journal of Infectious Diseases 207(5):721-729. https:// doi.org/10.1093/infdis/jis 745

von der Porten, S., J. Corntassel, and D. Mucina. 2019. Indigenous nationhood and herring governance: strategies for the reassertion of Indigenous authority and inter-Indigenous solidarity regarding marine resources. AlterNative: An International Journal of Indigenous Peoples 15(1):62-74. https://doi.org/10.1177/11771$\underline{80118823560}$

Weiss, M. 2020 $a$. Thanks for all the fish: a wild salmon story. The Economist 1843, 12 February. [online] URL: https:// www.1843magazine.com/dispatches/thanks-for-all-the-fish-a-wildsalmon-story

Weiss. M. 2020b. Citizen of the salmon world. Puget Sound Stories. The University of Puget Sound, Tacoma, Washington, USA. [online] URL: https://www.pugetsound.edu/stories/detail/ citizen-of-the-salmon-world/

Wexler, L. 2009. The importance of identity, history, and culture in the wellbeing of Indigenous youth. Journal of the History of Childhood and Youth 2(2):267-276.

White, S. C. 2017. Relational wellbeing: re-centring the politics of happiness, policy and the self. Policy \& Politics 45(2):121-136. https://doi.org/10/gd53q5

Wolfe, R., and R. J. Walker. 1987. Subsistence economies in Alaska: productivity, geography, and development impacts. Arctic Anthropology 24(2):56-81.

Woodhead, A. J., K. E. Abernethy, L. Szaboova, and R. A. Turner. 2018. Health in fishing communities: a global perspective. Fish and Fisheries 19:839-852. https://doi.org/10.1111/faf.12295

Young, O., and N. Einarsson. 2004. Introduction. Pages 1-15 in N. Einarsson, J. Nymand Larsen, A. Nilsson, and O. R. Young editors. Arctic human development report. Stefansson Arctic Institute, Akureyri, Iceland. 
Appendix 1. Well-Being Domains, Definitions, and Sample Indicators

\begin{tabular}{|c|c|c|c|}
\hline SASAP Domains & SASAP Dimensions & Definitions & Sample Indicators \\
\hline Economy \& Livelihood & Material Wealth \& Security & $\begin{array}{l}\text { Resources consumed, possessions, costs \& affordability, cost of living, basic needs, poverty, } \\
\text { debt, access to credit, material security, assets, and consumption }\end{array}$ & $\begin{array}{l}\text { \# of households below poverty line; Cost of living; Median household } \\
\text { income; Satisfaction with ability to provide for your family }\end{array}$ \\
\hline Economy \& Livelihood & $\begin{array}{l}\text { Economic Dimensions of } \\
\text { Resource Access }\end{array}$ & $\begin{array}{l}\text { Access to credit and capital needed to invest in gear, permits, etc. required for obtaining } \\
\text { resource; labor needed to harvest resource; market value of resource and access rights }\end{array}$ & $\begin{array}{l}\text { Entry costs; Value of fishing rights (compared to median household } \\
\text { income); Participation costs (as \% of total fisheries revenue); Are programs } \\
\text { or services in place to support local participation?; Access to capital (\% of } \\
\text { residents who qualify for fishing loan programs) }\end{array}$ \\
\hline Economy \& Livelihood & Local \& Informal Economies & $\begin{array}{l}\text { Production of and participation in food acquisition through subsistence, personal use, } \\
\text { recreational takes, and commercial home pack - broken out by demographic categories; } \\
\text { total harvest levels and exchange; fish/farmers markets, local producers \& consumers; } \\
\text { gifting, sharing, bartering, trading; value, volumes and percentages of reciprocal and in-kind } \\
\text { transactions; sharing networks }\end{array}$ & $\begin{array}{l}\text { Total salmon harvest by community (personal use, subsistence, } \\
\text { recreational, commercial homepack); Flow of different types of cash and } \\
\text { harvests between households; \# of households giving/sharing salmon (and } \\
\text { total \# of fish given/shared); \# of households receiving salmon (and total \# of } \\
\text { fish received); \# of personal use permits by community }\end{array}$ \\
\hline Economy \& Livelihood & Employment and Income & $\begin{array}{l}\text { Jobs, wages, and income (overall and by sector and social and demographic variables); } \\
\text { sector diversity within a population; unemployment and labor force participation; (see 'job } \\
\text { satisfaction' for other employment characteristics) }\end{array}$ & \begin{tabular}{|l|} 
Labor force participation rate; Unemployment rate; Distribution of income; \\
$\%$ of young adults that can't find work that want work; \% of population in \\
jobless households; \% of population employed in the salmon fishing \\
industry; Resident and nonresident workforce by fishery and industry sector
\end{tabular} \\
\hline Economy \& Livelihood & Job Satisfaction and Quality & $\begin{array}{l}\text { Job duration; employment options; living wage level; benefits; flexibility; job and work } \\
\text { satisfaction }\end{array}$ & $\begin{array}{l}\text { Satisfaction with job opportunities and upward mobility in community; } \\
\text { Job satisfaction by fishery and industry sector; Job stress by fishery and } \\
\text { industry sector; Job satisfaction by how many hours of work per week in } \\
\text { natural environment; \% of employed adults saying their job gives them a } \\
\text { sense of identity }\end{array}$ \\
\hline Economy \& Livelihood & $\begin{array}{l}\text { Subsistence and Traditional } \\
\text { Fishing \& Hunting Livelihoods }\end{array}$ & $\begin{array}{l}\text { Participation in traditional hunting and fishing practices, activities, and ways of life, } \\
\text { including harvesting, processing, storing, giving/receiving and consumption of subsistence } \\
\text { resources; satisfaction with traditional hunting and fishing livelihood opportunities, } \\
\text { activities and outcomes; perception and ability to respond to change \& uncertainty of } \\
\text { traditional lifeways }\end{array}$ & $\begin{array}{l}\text { \# of households harvesting subsistence salmon; Change in \# of fish camps } \\
\text { (and \# of families per fish camp); Is Amount Reasonably Neccesary for } \\
\text { Subsistence (ANS) met?; Total subsistence harvest (Ibs and \# of species); \% o } \\
\text { total subsistence harvest that is salmon; Local and nonlocal subsistence } \\
\text { harvest pressure; Satisfaction with your family's traditional hunting and } \\
\text { fishing opportunities }\end{array}$ \\
\hline Economy \& Livelihood & Commercial Fishing Livelihoods & $\begin{array}{l}\text { Participation in commercial fishing activities and practices, including harvesting, } \\
\text { processing, marketing, etc. of commercial fishery resources; change in local fishery } \\
\text { participation broken out by demographic and social variables; community employment } \\
\text { opportunity; mixed livelihoods that include commercial fishing; financial reinvestments in } \\
\text { local community; livelihood satisfaction }\end{array}$ & $\begin{array}{l}\text { Change in \# and \% of locally held fishing permits; Change in age distribution } \\
\text { of permit holders; Change in Alaska Native permit holdings; \# of new } \\
\text { entrants to fishery by age and residency; Average age of crew; \# and \% of } \\
\text { local and nonlocal crew licenses; \# and \% of local crew who feel they are } \\
\text { fairly paid; \# of local salmon permit holders holding access rights in other } \\
\text { fisheries; Lbs of subsistence salmon harvested by commercial fishery permit } \\
\text { holders; Change in catching power by residency of permit holder; Permit } \\
\text { latency rate by community }\end{array}$ \\
\hline Economy \& Livelihood & Recreation \& Tourism & $\begin{array}{l}\text { Participation in recreational fishing practices and activities, including harvesting and } \\
\text { guiding; recreation and tourism assets and opportunities }\end{array}$ & $\begin{array}{l}\text { \# of visitors to community per year; Relative contribution of local tourism } \\
\text { revenues within average annual household income; \# of recreational fishing } \\
\text { licenses sold in community; \# of local and nonlocal fishing lodges, services } \\
\text { or recreational guide outfitters; \# of sport fishing days; Satisfaction with } \\
\text { recreational opportunities in community }\end{array}$ \\
\hline
\end{tabular}




\begin{tabular}{|c|c|c|c|}
\hline Economy \& Livelihood & Local \& Informal Economies & $\begin{array}{l}\text { Production of and participation in food acquisition through subsistence, personal use, } \\
\text { recreational takes, and commercial home pack - broken out by demographic categories; } \\
\text { total harvest levels and exchange; fish/farmers markets, local producers \& consumers; } \\
\text { gifting, sharing, bartering, trading; value, volumes and percentages of reciprocal and in-kind } \\
\text { transactions; sharing networks }\end{array}$ & \begin{tabular}{|l|} 
Total salmon harvest by community (personal use, subsistence, \\
recreational, commercial homepack); Flow of different types of cash and \\
harvests between households; \# of households giving/sharing salmon (and \\
total \# of fish given/shared); \# of households receiving salmon (and total \# of \\
fish received); \# of personal use permits by community
\end{tabular} \\
\hline Economy \& Livelihood & Food Security & $\begin{array}{l}\text { Cost of food, food and water access, includes access to traditional foods, agricultural and } \\
\text { fisheries harvests; abundance, quality; food security and sovereignty; maintenance of } \\
\text { sharing networks; emergency preparedness }\end{array}$ & $\begin{array}{l}\text { Proportion of food to come from subsistence; Cost of food (consumer price } \\
\text { index); \# of adults who reported that household food money didn't last; } \\
\text { Availability and substitutability of preferred foods (i.e. Trends in targeting } \\
\text { new or different species because traditional or preferred species are } \\
\text { unavailable); Subsistence fishery closures; \% of households that report } \\
\text { having a stable food supply through the year; \% of households experiencing } \\
\text { food insecurity }\end{array}$ \\
\hline Economy \& Livelihood & Industry \& Commerce & $\begin{array}{l}\text { Commercial and industrial fisheries production, trade and revenue; GDP, investment, } \\
\text { general economic activity, business \& industry sector characteristics, commercial resource } \\
\text { harvests and extraction }\end{array}$ & $\begin{array}{l}\text { Total fisheries revenue in community and \% of revenue from salmon } \\
\text { fisheries; Gross fishery revenues per capita; Local economic activity from } \\
\text { salmon fishery; Vessel earnings and landings by community; Total fishery } \\
\text { earnings and landings }\end{array}$ \\
\hline Environment & Environmental Health \& Quality & $\begin{array}{l}\text { Quality or condition of natural environment and resources; ecosystem health, integrity, } \\
\text { productivity; water and soil quality; invasive species, habitat degradation; restored } \\
\text { habitats; quantity and geographic distribution of marine resources }\end{array}$ & $\begin{array}{l}\text { Abundance of selected key species; Are local salmon stocks listed as 'stocks } \\
\text { of concern' by Board of Fisheries?; Satisfaction with fish and game } \\
\text { availability; Satisfaction with health of salmon fisheries in your region; \% of } \\
\text { residents expressing concern for future health of salmon; Trends in public or } \\
\text { environmental health advisories related to fish harvest and consumption; } \\
\text { Do you have concerns about local water quality or habitat health?; Do you } \\
\text { have concerns about continamation or safety of consuming local fish and } \\
\text { game? }\end{array}$ \\
\hline Environment & $\begin{array}{l}\text { Ecological Dimensions of } \\
\text { Resource Access }\end{array}$ & $\begin{array}{l}\text { Attributes of a resource that make it available and desirable to potential users, such as } \\
\text { resource characteristics (size, maturity, abundance), condition (safe to eat), geographic } \\
\text { distribution; environmental conditions that affect access to resources or foster resource } \\
\text { availability (e.g. water quality, levels, etc. ) }\end{array}$ & $\begin{array}{l}\text { Change in range of available species (e.g. composition of commercial and } \\
\text { subsistence harvest by community); Availabilty of commonly harvested } \\
\text { species; Change in water levels or temperatures; Change in fish size, } \\
\text { condition or quality; Change in timing and availability of salmon }\end{array}$ \\
\hline Environment & Infrastructure & $\begin{array}{l}\text { Human built environment; roads, ports, housing and transit; communications and } \\
\text { technology infrastructure; community and municipal planning and development, urban } \\
\text { sprawl }\end{array}$ & $\begin{array}{l}\text { \# of fishing industry infrastucture (e.g. processors, boat ramps, harbors); } \\
\text { Satisfaction with local fishing infrastructure }\end{array}$ \\
\hline Environment & $\begin{array}{l}\text { Physical Dimensions of } \\
\text { Resource Access }\end{array}$ & $\begin{array}{l}\text { Physical infrastructure that affects resource access (e.g. roads, barriers, dams, harbors, } \\
\text { ports, boat ramps, public shoreline, etc.) }\end{array}$ & $\begin{array}{l}\text { \% of shoreline that is publicly accessible or owned; \% of residents who are } \\
\text { satisfied with their access to public shorelines or fishing sites (e.g. setnet, } \\
\text { dipnet, fish wheel sites); \# of local fishermen with access to seafood } \\
\text { markets/buyer for full harvest }\end{array}$ \\
\hline Environment & Pollution \& Waste & Anthropogenic pollution; biotoxin, marine debris; environmental well-being & $\begin{array}{l}\text { Marine debris collected annually; Trends in fishery/beach closures or public } \\
\text { or environmental health advisories related to pollutants/contaminants }\end{array}$ \\
\hline Environment & Beauty \& Inspiration & Aesthetic value, creativity and gratitude inspired by nature & $\begin{array}{l}\text { \% of residents who describe experiencing positive feelings/emotions from } \\
\text { being in nature, such as awe, inspiration, fulfillment, appreciation, } \\
\text { solitude, relaxation, sense of peace and reflection }\end{array}$ \\
\hline Health & Physical Health & $\begin{array}{l}\text { Health conditions; access to healthcare; nutrition, disease, injuries, life expectancy, birth } \\
\text { and death rates, mortality and morbundity; healthy food and lifestyle; healthy choices; } \\
\text { health advisories; perceptions of health }\end{array}$ & $\begin{array}{l}\text { \% of adults whose self-perceived health status is very good or excellent; \% of } \\
\text { adults who say they are in poor health; Life expectancy at birth (change over } \\
\text { time and disparities among populations); \% of residents who are } \\
\text { overweight/obese; Mortality and morbundity; Satisfaction with health } \\
\text { services; Satisfaction with your family's health; Hours of outdoor activity }\end{array}$ \\
\hline
\end{tabular}




\begin{tabular}{|c|c|c|c|}
\hline Economy \& Livelihood & Local \& Informal Economies & $\begin{array}{l}\text { Production of and participation in food acquisition through subsistence, personal use, } \\
\text { recreational takes, and commercial home pack - broken out by demographic categories; } \\
\text { total harvest levels and exchange; fish/farmers markets, local producers \& consumers; } \\
\text { gifting, sharing, bartering, trading; value, volumes and percentages of reciprocal and in-kind } \\
\text { transactions; sharing networks }\end{array}$ & \begin{tabular}{|l|} 
Total salmon harvest by community (personal use, subsistence, \\
recreational, commercial homepack); Flow of different types of cash and \\
harvests between households; \# of households giving/sharing salmon (and \\
total \# of fish given/shared); \# of households receiving salmon (and total \# of \\
fish received); \# of personal use permits by community
\end{tabular} \\
\hline Health & Spiritual Health & $\begin{array}{l}\text { Participation in spiritual practices, ceremonies, and religion without risk of persecution or } \\
\text { perceived persecution; maintenance of community, family, ancestral and human/non- } \\
\text { human relationships and connectedness; transgenerational and historical traumas }\end{array}$ & $\begin{array}{l}\text { \% of residents who feel they are able to practice their spiritual or religious } \\
\text { beliefs without persecution or discrimination; \% of residents who have } \\
\text { experienced multi-generational trauma due to colonialism or other } \\
\text { historical oppressions; Qualitative assessment of practices and conditions } \\
\text { that promote and threaten spiritual well-being }\end{array}$ \\
\hline Safety & Physical Safety & $\begin{array}{l}\text { Safety at work and home; occupational risks and emergency services, building codes, } \\
\text { injuries }\end{array}$ & $\begin{array}{l}\text { \# of fishery related injuries or deaths; \% of people who feel safe in their } \\
\text { communities; \% of households feeling safe, moderately safe or not safe from } \\
\text { property crime in community }\end{array}$ \\
\hline Safety & Peace \& Security & $\begin{array}{l}\text { Presence, absence, and prevention of violence; crime, non-compliance, emergency services, } \\
\text { sense of personal safety, acts of violence, refugees including environmental refugees }\end{array}$ & $\begin{array}{l}\text { Sense of safety; Crime rate by community; \# of emergency calls; Average } \\
\text { response time for emergency services; Satisfaction with public safety }\end{array}$ \\
\hline Culture, Place \& Identity & Cultural Values \& Practices & $\begin{array}{l}\text { Culture, language, \& the arts; languages spoken; cultural sites; cultural practices and values; } \\
\text { meaning of practices; environmental ethos and values; community and cultural events }\end{array}$ & \begin{tabular}{|l|} 
Are Indigenous language learning opportunities available in community?; \\
Satisfaction with ability to understand, speak, write your Indigenous \\
language; Are you able to participate in cultural activities or traditions that \\
are important to your family or community? (How easy or difficult are these \\
to maintain?); Satisfaction with community promotion of cultural values; \\
Satisfaction with sharing and helping in your community
\end{tabular} \\
\hline Culture, Place \& Identity & $\begin{array}{l}\text { Generational Connections to } \\
\text { Place and Culture }\end{array}$ & $\begin{array}{l}\text { Multi-generational connections and interactions with place, environment and natural } \\
\text { resources; archeological and historic sites; cultural resources; acceptable historical change }\end{array}$ & $\begin{array}{l}\text { Satisfaction with your ability to learn traditional skills and knowledge in } \\
\text { your community; \% of residents that participate in practices important to } \\
\text { their connection to place; Age structure of residents that participate in } \\
\text { practices important to their connection to place; Are there elders or } \\
\text { Indigenous community members with knowledge of tribal traditions and } \\
\text { places in the community? }\end{array}$ \\
\hline Culture, Place \& Identity & $\begin{array}{l}\text { Place Attachments \& Sense of } \\
\text { Place }\end{array}$ & $\begin{array}{l}\text { Meaning and identity connected to place; activities on the landscape, heritage, social and } \\
\text { emotional connections to places and lands/waters }\end{array}$ & $\begin{array}{l}\text { \% of residents who express high life satisfaction or happiness and \% who } \\
\text { express living in the region as a contributor to this; \% of local youth who } \\
\text { feel that community is a good place to grow up; \% of residents who feel } \\
\text { attachment to place is threatened }\end{array}$ \\
\hline Culture, Place \& Identity & $\begin{array}{l}\text { Religion, Spirituality \& } \\
\text { Worldviews }\end{array}$ & $\begin{array}{l}\text { Sense of spirituality; belief systems; rituals and ceremonies; ways in which cosmologies, } \\
\text { ideologies, and everyday practices shape relationships to and ways of being with and } \\
\text { thinking about the environment, humans, ancestors, and non-human beings }\end{array}$ & \begin{tabular}{|l|} 
Spiritual fulfillment; Is your worldview shared by decision-makers?; \\
Qualitative assessment of ways in which people-nature relationships shape \\
worldviews or belief systems
\end{tabular} \\
\hline Culture, Place \& Identity & Stewardship \& Values & $\begin{array}{l}\text { Active conservation and sustainability practices, includes protected areas, restoration, } \\
\text { recycling, etc.; taking care of land and water; environmental ethos, conservation ethic, } \\
\text { human-nature relationships }\end{array}$ & $\begin{array}{l}\text { \% of residents engaging in salmon stewardship activities per year; } \\
\text { Satisfaction with impact your stewardship actvitities have on reducing } \\
\text { environmental problems or threats; Are your stewardship values shared by } \\
\text { fishery decision-makers? }\end{array}$ \\
\hline
\end{tabular}




\begin{tabular}{|c|c|c|c|}
\hline Economy \& Livelihood & Local \& Informal Economies & $\begin{array}{l}\text { Production of and participation in food acquisition through subsistence, personal use, } \\
\text { recreational takes, and commercial home pack - broken out by demographic categories; } \\
\text { total harvest levels and exchange; fish/farmers markets, local producers \& consumers; } \\
\text { gifting, sharing, bartering, trading; value, volumes and percentages of reciprocal and in-kind } \\
\text { transactions; sharing networks }\end{array}$ & \begin{tabular}{|l|} 
Total salmon harvest by community (personal use, subsistence, \\
recreational, commercial homepack); Flow of different types of cash and \\
harvests between households; \# of households giving/sharing salmon (and \\
total \# of fish given/shared); \# of households receiving salmon (and total \# of \\
fish received); \# of personal use permits by community
\end{tabular} \\
\hline Social Relationships & $\begin{array}{l}\text { Family and Community } \\
\text { Connections }\end{array}$ & $\begin{array}{l}\text { Family, personal relationships, joint family endeavors, community support and } \\
\text { relationships, marriage and divorce, community spaces }\end{array}$ & $\begin{array}{l}\text { \% of residents who are caring for dependents (and \% for whose care of } \\
\text { others depends on access to salmon); \% of adults giving unpaid care to } \\
\text { seniors/elders; \% of } 16-24 \text { year olds who think it would be difficult to find a } \\
\text { marriage partner in community ; \# of respondents with other family } \\
\text { members living in-region; \% of population who respond they can count on } \\
\text { other community members to come to their assistance in a crisis; Social } \\
\text { capial (total \# of community groups that respondent belongs to) }\end{array}$ \\
\hline Social Relationships & $\begin{array}{l}\text { Social Dimensions of Resource } \\
\text { Access }\end{array}$ & $\begin{array}{l}\text { Social context, identity and networks of the resource user that enable, confer or deny rights } \\
\text { of access, e.g. ethnicity, kinship, group membership }\end{array}$ & $\begin{array}{l}\text { \% of new entrants to fishery that do not come from fishing family; \# of } \\
\text { fishing permits within family; \% of annual permit transfers that are gifted to } \\
\text { family/friend vs. sold/transferred; \# of young residents who anticipate being } \\
\text { gifted a fishing permit from family/friend; \# of local vessels participating in } \\
\text { fishery ; \# of residents with historical ties to fishery that no longer fish }\end{array}$ \\
\hline Social Relationships & Generational Continuity & Ancestry; lineage identity, generational solidarity & $\begin{array}{l}\text { \# of continuous generations harvesting resource; \% of children under age } 16 \\
\text { that fish with family or friends }\end{array}$ \\
\hline Social Relationships & Non-human social relationships & $\begin{array}{l}\text { Worldviews, values and belief systems governing relationships with non-human life, } \\
\text { including plants and animals, land and water }\end{array}$ & ethnographic and/or qualitative assessment of people-nature relationships \\
\hline Social Relationships & Social integrity & $\begin{array}{l}\text { Social fabric and trust in people, trust in neighbors, inter-group relations, sense of } \\
\text { community }\end{array}$ & $\begin{array}{l}\text { \% of people who say they feel part of the community; \% of population who } \\
\text { agree there are opportunities to contribute to their community; Trust: how } \\
\text { much respondents trusted community members, local leaders, police, and } \\
\text { local government }\end{array}$ \\
\hline Education \& Knowledge & Education \& Information & Possession \& transmission of knowledge, information \& skills & $\begin{array}{l}\text { Residents aged 16-64 with no qualifications; \% of residents who agree they } \\
\text { have access to enough information regarding decisions affecting their } \\
\text { community; Satisfaction with opportunities to learn new skills and } \\
\text { knowledge in your community }\end{array}$ \\
\hline Education \& Knowledge & \begin{tabular}{|l|} 
Cognitive $\&$ Cultural \\
Dimensions of Resource Access
\end{tabular} & $\begin{array}{l}\text { Knowledge required to identify, locate, harvest and process resource; values and ethics } \\
\text { about which resources to harvest and quantities }\end{array}$ & $\begin{array}{l}\text { \% of residents who agree that they have access to enough information to } \\
\text { harvest and care for salmon (e.g. operate gear/vessel, handle fish, etc.) }\end{array}$ \\
\hline Education \& Knowledge & Local \& Traditional Knowledge & $\begin{array}{l}\text { Embedded systems of knowledge within place-based and cultural traditions and experience; } \\
\text { knowledge, values, ways of thinking across systems and beliefs actively passed down } \\
\text { through generations }\end{array}$ & $\begin{array}{l}\text { Elder satisfaction with youth ability to understand and learn traditional } \\
\text { skills and knowledge; Trends in \% of elders or parents transmitting } \\
\text { traditional knowledge to children; Satisfaction with ability of salmon } \\
\text { managers to incorporate local and traditional knowledge into decision- } \\
\text { making; Does community organize a salmon/culture camp for local youth } \\
\text { and residents? }\end{array}$ \\
\hline Education \& Knowledge & Research \& Technology & $\begin{array}{l}\text { Production of new tools and data; ability to produce/contribute new knowledge; access to } \\
\text { technology }\end{array}$ & $\begin{array}{l}\text { \% of households with broadband access; Satisfaction with community } \\
\text { engagement in salmon research design and data collection }\end{array}$ \\
\hline Education \& Knowledge & $\begin{array}{l}\text { Technical Dimensions of } \\
\text { Resource Access }\end{array}$ & $\begin{array}{l}\text { The technical skills, equipment, etc. required to harvest resources, such as fishing gear, } \\
\text { location devices, boats }\end{array}$ & $\begin{array}{l}\text { \# of USCG registered vessels by community; Do you have access to the } \\
\text { tools/gear you need to harvest salmon? }\end{array}$ \\
\hline
\end{tabular}




\begin{tabular}{|c|c|c|c|}
\hline Economy \& Livelihood & Local \& Informal Economies & $\begin{array}{l}\text { Production of and participation in food acquisition through subsistence, personal use, } \\
\text { recreational takes, and commercial home pack - broken out by demographic categories; } \\
\text { total harvest levels and exchange; fish/farmers markets, local producers \& consumers; } \\
\text { gifting, sharing, bartering, trading; value, volumes and percentages of reciprocal and in-kind } \\
\text { transactions; sharing networks }\end{array}$ & \begin{tabular}{|l|} 
Total salmon harvest by community (personal use, subsistence, \\
recreational, commercial homepack); Flow of different types of cash and \\
harvests between households; \# of households giving/sharing salmon (and \\
total \# of fish given/shared); \# of households receiving salmon (and total \# of \\
fish received); \# of personal use permits by community
\end{tabular} \\
\hline Voice \& Agency & Self-Determination & $\begin{array}{l}\text { Independence, agency, freedom from social or governmental constraints; ability to make } \\
\text { meaningful decisions, includes groups' ability to enact their own healing }\end{array}$ & $\begin{array}{l}\text { Are traditional marine and coastal use rights recognized?; Are you able to } \\
\text { pursue your fishing way of life in a way that you would like to? }\end{array}$ \\
\hline Voice \& Agency & Sovereignty & Tribal or local sovereignty; self governance (see also Resource Management) & $\begin{array}{l}\text { Is there an Alaska Native right or Tribal access in fishery?; Satisfaction with } \\
\text { local control over fish and game management; Land ownership (\% of local } \\
\text { waters/lands under state/federal/tribal jurisdiction, etc.); \% of } \\
\text { regions/communities/Tribes that have completed a strategic cooperative } \\
\text { salmon management arrangement; Are lands and waters managed or co- } \\
\text { managed by Indigenous or local communities? }\end{array}$ \\
\hline Voice \& Agency & Voice & Having a voice in decision-making & $\begin{array}{l}\text { \% of residents who agree they have input in resource management } \\
\text { decisions; Trends in local participation in mangement meetings; } \\
\text { Satisfaction with your influence over local politics and leadership; } \\
\text { Satisfaction with influence you have over management of fish and game }\end{array}$ \\
\hline Voice \& Agency & $\begin{array}{l}\text { Political Dimensions of } \\
\text { Resource Access }\end{array}$ & $\begin{array}{l}\text { Ability to raise issues before decision-makers; influence, power, local control, political } \\
\text { representation; voice and participation in management }\end{array}$ & $\begin{array}{l}\text { Do salmon managers and decision-makers live in your region?; How often } \\
\text { are salmon management meetings held in your community?; Cost to } \\
\text { participate in management meetings; ls your community represented on a } \\
\text { formal advisory board/council to a regulatory body?; \# of local fishing } \\
\text { ordinances developed by Tribe; \# of fishery proposals/plans developed by } \\
\text { community (success rate?) }\end{array}$ \\
\hline Management \& Governance & Resource Management & $\begin{array}{l}\text { Governmental management of natural resources, including governing institutions, self- } \\
\text { governance and tribal or local sovereignty; perceptions and effectiveness of management; } \\
\text { capacity for achieving management objectives }\end{array}$ & $\begin{array}{l}\text { Satisfaction with salmon management; Diversity of salmon users included } \\
\text { in management; Are the people who most need salmon able to get salmon?; } \\
\text { How equitable is the distribution of access rights across user groups?; } \\
\text { Satisfaction with family's access to fishing opportunities; Is salmon } \\
\text { management adequately funded? }\end{array}$ \\
\hline Management \& Governance & $\begin{array}{l}\text { Legal Dimensions of Resource } \\
\text { Access }\end{array}$ & $\begin{array}{l}\text { Laws, policies, rules (customary or de jure), permits, quota, regulation, etc. that govern } \\
\text { access to resources }\end{array}$ & $\begin{array}{l}\text { How would you rate the fairness of salmon management?; Fishery or area } \\
\text { closures; Is access based on traditional or historical access and harvests?; } \\
\text { Are access rights provided to those that live closest to the resource? }\end{array}$ \\
\hline Management \& Governance & General Governance & $\begin{array}{l}\text { Principles and practices of effective governance, includes western and tribal governance; } \\
\text { public debt, taxes, expenditures; inter-agency coordination; transparency }\end{array}$ & $\begin{array}{l}\text { Confidence in institutions and leaders; Perceptions of } \\
\text { transparency/legitimacy of governance systems; \% of residents satisfied } \\
\text { with the quality of local government and leadership }\end{array}$ \\
\hline Management \& Governance & Civic Participation & $\begin{array}{l}\text { Community volunteering, regulatory meeting attendance, service (boards, government, } \\
\text { committees, etc). }\end{array}$ & $\begin{array}{l}\text { \% of residents who have worked with other residents to solve community } \\
\text { challenges; \% of residents serving on local boards/councils/bodies; \% of } \\
\text { eligible population registered to vote (and voter turnout); \% of adults who } \\
\text { volunteer for community activities }\end{array}$ \\
\hline
\end{tabular}

